NBER WORKING PAPER SERIES

\title{
DOES THE LACK OF FINANCIAL STABILITY IMPAIR THE TRANSMISSION OF MONETARY POLICY?
}

\author{
Viral V. Acharya \\ Björn Imbierowicz \\ Sascha Steffen \\ Daniel Teichmann \\ Working Paper 26479 \\ http://www.nber.org/papers/w26479 \\ NATIONAL BUREAU OF ECONOMIC RESEARCH \\ 1050 Massachusetts Avenue \\ Cambridge, MA 02138 \\ November 2019
}

The views expressed are those of the authors and do not represent the views of the Deutsche Bundesbank, the Eurosystem, or the National Bureau of Economic Research. We thank Tobias Berg, Martin Brown, Matteo Crosignani, John Driscoll, Falko Fecht, André Güttler, Ralph de Haas, Hendrik Hakenes, Florian Heider, Neeltje van Horen, Stephan Jank, Martin Kanz, David Lando, David Marques-Ibanez, David Martinez-Miera, Emanuel Mönch, Steven Ongena, Andrea Polo, Lasse Heje Pedersen, Adriano Rampini, Asani Sarkar, Morton Sørensen, Daniel Streitz, Harald Uhlig, and participants in the 2014 European Summer Symposium in Financial Markets, the 2014 ECB workshop on "Non-standard monetary policy measures," the 2014 Bank Workshop in Münster, the 2015 FIRS meetings, the 2015 Bocconi/Carefin Conference, the 2015 Summer Research Conference in Finance at ISB, the 2015 FED conference on "Monetary Policy Implementation and Transmission in the Post-Crisis Period," the 2015 Financial Management Association, the Bundesbank/CEPR Conference "One year after the European Banking Union take-off," the China International Conference in Finance, the 1st IWH-FIN-FIRE Workshop on "Challenges to Financial Stability," the 2nd Conference on "Bank performance, financial stability and the real economy," the 4th MoFiR workshop on banking, and seminar participants at the Bank of England, Copenhagen Business School, Erasmus University Rotterdam, European Bank for Reconstruction and Development, Frankfurt School of Finance and Management, Tilburg University, the University of Mannheim and University of Ulm for valuable comments and suggestions. Imbierowicz gratefully acknowledges support from the Center for Financial Frictions (FRIC), grant no. DNRF102.

NBER working papers are circulated for discussion and comment purposes. They have not been peerreviewed or been subject to the review by the NBER Board of Directors that accompanies official NBER publications.

(C) 2019 by Viral V. Acharya, Björn Imbierowicz, Sascha Steffen, and Daniel Teichmann. All rights reserved. Short sections of text, not to exceed two paragraphs, may be quoted without explicit permission provided that full credit, including $(\odot$ notice, is given to the source. 
Does the Lack of Financial Stability Impair the Transmission of Monetary Policy?

Viral V. Acharya, Björn Imbierowicz, Sascha Steffen, and Daniel Teichmann

NBER Working Paper No. 26479

November 2019

JEL No. E43,E58,G01,G21

\section{$\underline{\text { ABSTRACT }}$}

We investigate the transmission of central bank liquidity to bank deposits and loan spreads in Europe over the period from January 2006 to June 2010. We find evidence consistent with an impaired transmission channel due to bank risk. Central bank liquidity does not translate into lower loan spreads for high-risk banks for maturities beyond one year, even as it lowers deposit spreads for both high-risk and low-risk banks. This adversely affects the balance sheets of highrisk bank borrowers, leading to lower payouts, capital expenditures and employment. Overall, our results suggest that banks' capital constraints at the time of an easing of monetary policy pose a challenge to the effectiveness of the bank-lending channel and the central bank's lender-of-lastresort function.

Viral V. Acharya

Stern School of Business

New York University

44 West 4th Street, Suite 9-65

New York, NY 10012

and CEPR

and also NBER

vacharya@stern.nyu.edu

Björn Imbierowicz

Deutsche Bundesbank

Wilhelm-Epstein-Strasse 14

Germany

bjorn.imbierowicz@gmail.com

\author{
Sascha Steffen \\ Frankfurt School of Finance \& Management \\ Germany \\ s.steffen@fs.de \\ Daniel Teichmann \\ Goethe University Frankfurt \\ House of Finance \\ Theodor-W.-Adorno-Platz 3 \\ Frankfurt 60323 \\ Germany \\ Daniel.teichmann@hotmail.com
}


[...] it is nonetheless useful to recall again the limits of monetary policy. Monetary policy transmission may be hampered at times where banks, in particular, but also non-financial sectors need to repair their balance sheets. At times of uncertainty and lack of confidence, liquidity may be hoarded rather than be put to use for investment. These are cases where standard monetary policy may be "pushing on a string" (in the words of John Maynard Keynes). These are also impediments that need to be fundamentally addressed by regulators and government entities, via the strengthening of financial balance sheets $[\ldots]$

(Yves Mersch, Member of the Executive Board of the ECB, May 2013)

\section{Introduction}

Monetary policy impacts the supply of bank credit, implying a bank-lending or risk-taking channel of monetary policy. ${ }^{1}$ The key mechanism behind the bank-lending channel is agency costs between banks and their financiers. The empirical approach in this literature, however, usually ignores that banks fund their lending activities to a large extent with short-term wholesale deposits and that monetary policy also affects deposit rates. ${ }^{2}$ However, the connection between monetary policy and deposit rates is important as an impaired transmission channel might originate in the funding market, for example, because some banks are undercapitalized and face regulatory and economic constraints, even if monetary policy is expansive. However, we know very little about how monetary policy affects the market for corporate deposits. For example, does monetary policy transmit equally to deposit and loan rates? Can the transmission of monetary policy still be impaired even if central banks provide unlimited short-term liquidity to banks, effectively guaranteeing also (uninsured) wholesale deposits? And, what are the implications for customers of banks, both lenders (i.e. depositors) and borrowers? These are the main questions we try to address in this paper, thereby providing evidence on the effectiveness of the bank-lending channel and on central banks as lenders of last resort.

\footnotetext{
${ }^{1}$ Researchers argue that (1) monetary policy affects loan supply by banks (Bernanke and Gertler, 1989, 1995; Kashyap and Stein, 2000); (2) the reduction in loan supply is due to weak bank balance-sheet strength (Bernanke and Blinder, 1988; Bernanke, 2007; Jiménez et al., 2012); and (3) a low monetary policy rate increases risk-taking by banks (Jiménez et al., 2014; Ioannidou et al., 2015; Dell'Ariccia et al., 2017).

${ }^{2}$ An important exception is Drechsler et al. (2017) who argue that the deposit channel of monetary policy can explain a large part of the bank balance-sheet channel.
} 
Our setting is the introduction of the full allotment of liquidity by the ECB in October 2008 as a response to the deepening of the global financial crisis. Prior to that date, the ECB issued liquidity to banks in a competitive tender to meet an aggregate liquidity target. Liquidity was allocated to the banking sector such that each bank could meet its reserve requirements. After the default of Lehman Brothers in September 2008, the interbank markets became severely stressed (Afonso, Kovner and Schoar, 2011) preventing an efficient allocation of liquidity among banks. On October 8, 2008, the ECB began to fulfill all liquidity requests by individual banks at the prevailing main refinancing (MRO) rate in exchange for collateral via its main refinancing operations, which eventually provided substantial excess liquidity to the banking system.

We construct a novel data set of deposit and loan transactions of the same banks during the January 2, 2006 to June 30, 2010 period and investigate the impact of "aggregate" central bank liquidity (i.e., the total liquidity in the banking system provided by the ECB) on spreads of newly issued deposits and loans before and after the introduction of the full-allotment liquidity concept, exploiting cross-sectional differences in the health of these European banks. As the introductory quote suggests, during financial crises, the transmission of monetary policy might be impaired due to the weak balance sheets of some banks. To the best of our knowledge, we are the first to analyze where the transmission channel is impaired-the funding or the loan market. This is important for understanding the role of central banks in addressing liquidity versus solvency problems during crises, as well as for the design of crisis-time monetary policy interventions.

We focus on deposit contracts in the first part of the paper and analyze how central bank liquidity affects corporate deposit spreads for high- versus low-risk banks. There are two main identification challenges: central bank liquidity might be endogenous and driven by current market conditions; in addition, deposit spreads, as well as amounts, might be driven by demand and supply effects in the market for corporate deposits. We address this in two ways. First, we 
explore the sensitivity of our results to the inclusion of controls and fixed effects and argue that our main coefficients remain almost unaffected. We then use a three-equation system to isolate a deposit demand function using instruments to shift both central bank liquidity provision and corporate deposit supply.

Our first main result is that an increase in central bank liquidity is associated with a significant decrease in bank deposit spreads during the financial crisis. This effect is economically large in magnitude. During the financial crisis, a one standard deviation increase in liquidity reduces deposit spreads by about 3 bps before, and 8 bps after the introduction of the full-allotment policy. Differentiating by bank risk, which we measure using banks' credit default swaps spreads, we find that the deposit spreads of low-risk banks_-but not of high-risk banks-decrease in response to larger amounts of liquidity prior to the beginning of the full allotment period. Thereafter, both high- and low-risk banks similarly reduce deposit spreads when central bank liquidity increases.

We next trace out supply and demand functions for corporate deposits from our data during the full-allotment period and show that, holding everything else constant, firms supply more deposits when banks offer higher spreads. In other words, the deposit supply function is upward sloping. Banks' demand for deposits is downward sloping, i.e. if the provision of deposits is higher, then the marginal utility of deposits is lower, which reduces deposit spreads. The slope coefficient of the supply function is lower, suggesting that the supply of deposits is relatively inelastic with respect to deposit spreads. Importantly, we show that an increase in central bank liquidity shifts the deposit demand curve inwards and that both high- and low-risk banks pay less for corporate deposits, with all else equal.

Taken together, the deposit spread differential suggests that an increase in central bank liquidity before the introduction of the full-allotment policy was insufficient to reduce the funding risks of high- and low-risk banks. High-risk banks needed to pay substantially higher deposit spreads to compensate depositors and attract funds. Interbank markets were 
dysfunctional prior to the full allotment period and low-risk banks in particular hoarded liquidity (Afonso, Kovner, and Schoar, 2011). The ECB then stepped in as lender of last resort (LOLR), meeting all banks' liquidity requests in full. At the same time, it extended the list of assets accepted as eligible collateral for refinancing operations. Substituting for the loss of private funding, the ECB eventually reduced the funding pressure of high-risk banks.

We then investigate how the ECB interventions as a LOLR translate into banks' loanlending decisions using the same set of banks that we observe in the deposit market. We do not find (in contrast to the deposit market) a differential impact of ECB liquidity on loan spreads for low- versus high-risk banks prior to the introduction of the full-allotment policy; the loan spreads do not respond to central bank liquidity changes for either high- or low-risk banks. After the introduction, however, the loan spreads of low-risk banks decrease, while they remain unchanged for high-risk banks when the ECB increased its liquidity provision. A one standard deviation increase in ECB liquidity decreases the loan spreads of low-risk banks by about 27 bps relative to high-risk banks during the full-allotment period, which is economically meaningful given an average loan spread of about 306 bps. In addition, we investigate the passthrough of monetary policy during the full-allotment policy for different loan maturities. Our results suggest that the transmission channel is impaired, particularly for loans beyond a maturity of one year.

We then focus on borrowers that borrow from the same group of either low- or highrisk banks before and after the full-allotment period (intensive margin). To investigate the differential effect of central bank liquidity for high-risk versus low-risk banks, we use a Heckman regression model, thereby addressing concerns that firms self-select into loan-lending relationships with these banks. We also match borrowers of low- and high-risk banks in the full-allotment period using propensity score matching models. We find consistent results.

An interesting question might be why borrowers do not switch when high-risk banks demand higher loan spreads relative to low-risk banks. We show that high-risk banks charge 
higher loan spreads particularly to bank-dependent borrowers, which are typically small- and medium-sized firms as well as firms without a public debt rating. This is consistent with evidence in Fazzari, Hubbard and Petersen (1988), Gertler and Gilchrist (1994) and Kashyap, Lamont and Stein (1994), who use similar proxies for borrowers' financial constraints and reliance on external funding.

Finally, we investigate the real consequences for borrowers of high- versus low-risk banks due to the ECB's liquidity framework. While the borrowers of high-risk banks increase their credit lines relative to their term-loan borrowing following the ECB's liquidity provision, these firms also invest less, have lower capital expenditures and reduce the number of employees.

To summarize, we find evidence that the transmission channel of monetary policy in the euro area is impaired in the loan market but not the deposit market even after the introduction of the ECB's full-allotment policy. This evidence shows that banking sector balance-sheet weakness limited the role of the ECB as LOLR during financial crises and is associated with negative real effects of bank-dependent borrowers of high-risk banks.

It is noteworthy that high-risk banks that charge higher loan spreads to bank-dependent customers might benefit from an increase in central bank liquidity. As the ECB effectively provided unlimited liquidity at a low interest rate, banks lowered deposit rates and refinanced their loans at lower funding costs. Not passing on these lower funding costs to borrowers increased the margins of high-risk banks—and thus their net worth—relaxing both regulatory and economic constraints. Hence, an increase in central bank liquidity essentially amounted to a "stealth recapitalization" of high-risk banks consistent with theoretical models e.g. in Brunnermeier and Sannikov (2016). An alternative view is that high-risk banks are reaching for yield. We discuss this view and implications in Section 8 of this paper.

The rest of the paper is organized as follows. In Section 2, we discuss the related literature and contributions of our paper. We then describe the institutional setting (Section 3) 
and data (Section 4). We next discuss the effect of central bank liquidity on deposit rates in Section 5 and on loan spreads in Section 6. In Section 7, we discuss the implications for the real sector and conclude in Section 8.

\section{Related literature}

We review the related literature and discuss our contributions to the literature in this section. Many researchers have investigated the pass-through of monetary policy on bank loan supply through the bank-lending channel and its associated real effects (Kashyap and Stein, 1994; Peek and Rosengren, 2015). In this literature, banks with different balance sheets (e.g. based on leverage, liquidity or asset size) respond differently to monetary policy shocks (Kashyap and Stein, 1995; 2000; Kishan and Opiela, 2000; Campello, 2002; Gambacorta and Mistrulli, 2004; Jiménez et al., 2012; Gomez et al., 2016). These researchers, however, do not consider how bank deposit and loan markets interact. Moreover, an important dimension of the pass-through is not only the quantity but also the pricing of deposits and loans as weak banks have incentives to increase their margins to relax regulatory and economic constraints.

Importantly, this literature highlights that banks with weak balance sheets are more responsive to monetary policy because of agency problems between banks and their financiers. Consequently, and studying a period outside of financial crises, Jiménez et al. (2012) conjecture that an expansive monetary policy during crises might be prudent as weak banks react stronger to tightening of monetary policy during normal times. That is, this literature suggests a symmetric effect of contractionary and expansionary monetary policy with respect to the responsiveness of banks to these measures. Our results, however, suggest the opposite: weak banks do not respond to expansionary monetary policy measures in the loan markets but strong, well-capitalized banks do. The key difference in our paper is that aforementioned agency costs are attenuated during the full-allotment period when the ECB provides unlimited liquidity to all banks (weak and strong), thus effectively providing insurance also to short-term wholesale depositors. But even during this period, weak banks still charge higher loan spreads compared 
to strong banks. In other words, while the effect in the previous literature originates mainly in funding liquidity problems of weak banks, we show that the main driver of higher loan spreads of weak relative to strong banks is rooted in their solvency conditions. Thus, as far as the transmission by weak bank balance sheets to the real sector is concerned, monetary policy easing might be "pushing on a string" as long as financial sector stability is not restored.

Comparing the credit default swap (CDS) spreads of banks during the February 2002 to December 2008 period (which is the sample period in Jiménez et al. (2012)) to our sample period of January 2006 to June 2010 is compelling. We find that weak banks had an average CDS spread of only 17 bps during the sample period analyzed in Jiménez et al. (2012). Strong banks in our sample period, on the other hand, had an average CDS spread of $23 \mathrm{bps}$. That is, the absolute level of risk appears to be important. During the global financial crisis, bank health substantially deteriorated due to high leverage and poor-quality assets. In turn, solvency risks spilled over into short-term funding markets. Consequently, monetary policy transmission and central bank liquidity allocation in short-term funding markets were impaired until the ECB stepped in as LOLR and provided abundant liquidity for high- and low-risk banks. The ECB thus successfully reduced tensions in the money market. However, this intervention was not adequate for the loan market, likely due to bank solvency concerns: high-risk banks kept loan interest rates, ceteris paribus, higher than low-risk banks, consistent with the theoretical predictions in Brunnermeier and Sannikov (2016).

Our paper also relates to the literature that more broadly shows that bank loan supply declines during financial crises when the banking system is weak (Peek and Rosengren, 1995, Ivashina and Scharfstein, 2010, Popov and van Horen, 2015). In a recent paper, Heider et al. (2019) demonstrate a special role of deposits for bank loan supply when policy rates become negative. We add to this literature by documenting empirically that large liquidity injections by central banks do not reduce financial frictions of bank-dependent firms if the banking sector is 
undercapitalized. Moreover, we show that short-term liquidity provisions do not improve longterm lending, even among well-capitalized banks.

\section{Institutional setting}

In order to understand the effect of central bank liquidity on deposit and loan spreads, it is useful to briefly review the standard instruments of monetary policy in the eurozone (e.g., open market operations, standing facilities, and minimum reserve requirements), and to highlight the ECB's major policy changes.

In contrast to the United States, where open market operations are primarily conducted by buying Treasury bonds, the ECB uses its main refinancing operations (MRO) to provide liquidity to financial institutions in exchange for collateral (repurchase agreements) in fixedrate or variable-rate tenders. These operations are usually conducted on a weekly basis and have a maturity from one week up to three months. By increasing or reducing interest rates in MROs, as well as changing the size of the allotment, the ECB can affect both market interest rates and liquidity. The ECB follows a liquidity-neutral allotment concept (i.e., liquidity provision is based on its assessment of the liquidity needs of the banking system in the eurozone).

The ECB can provide and absorb overnight liquidity using its standing facilities. Banks can use the deposit facility to make unlimited overnight deposits at an interest rate that is usually (at least before the financial crisis started) $1 \%$ below the MRO rate. Banks can use the marginal lending facility to obtain overnight liquidity that is usually $1 \%$ above the MRO rate. The available collateral restricts the amount a bank can borrow. The standing facilities thus provide a corridor for overnight interest rates.

Monetary policy also includes minimum reserve requirements, which require banks to hold deposits on accounts in the Eurosystem that reflect the amount of the banks' customer deposits. The ECB uses minimum reserve requirements to smooth short-term interest rates by averaging positions over a specific period. The minimum reserves are remunerated at the MRO rate. Excess reserves, however, are transferred to the deposit facility. That is, banks usually 
hold only the minimum reserves at the ECB if money markets are able to redistribute liquidity from banks with a liquidity surplus to banks with a liquidity deficit. In the pre-crisis period, there was no need to hold excess reserves at the ECB, as liquidity was readily available in the money markets, and central bank liquidity was determined by reserve requirements. The recent financial crisis, however, had a profound impact on European money markets. Banks became increasingly reluctant to lend to each other, which led to further segmentation of this market, particularly in cross-border transactions. The three-month EURIBOR-OIS swap spread, the difference between the euro interbank offered rate and overnight indexed swaps, increased to more than 200 bps during the August 2007 to October 2008 period, emphasizing the stress in money markets in the eurozone.

The ECB was not able to sustain its liquidity-neutral allotment concept during the financial crisis because it became increasingly difficult to forecast the liquidity needs of the banking system. The ECB therefore changed its liquidity provision framework on October 8 , 2008 to fully satisfy bank demand for liquidity at a fixed interest rate (fixed-rate full-allotment), effectively also guaranteeing (uninsured) wholesale depositors. This shift in liquidity provision substantially increased the aggregate liquidity in the banking system, which is reflected in a sharp increase of funds in the deposit facility. The fixed-rate full-allotment procedure will continue at least until the end of the last reserve maintenance period of 2019.

\section{Data}

\subsection{Sample selection}

To investigate the effect of central bank liquidity on deposit spreads, we employ a unique and proprietary data set including corporate deposits from a European trading platform that ranks among the three largest platforms by volume in Europe. The deposits are sizable. The average deposit amount on a specific day with each bank over a one-year period corresponds to about 
$15 \%$ of a bank's end of year short-term liabilities. ${ }^{3}$ Prior to trading, banks and firms agree on the procedures and execution of trades and sign a framework agreement. This agreement applies to all future trades on the platform. Firms can offer any deposit amount with any maturity. All banks using the platform observe this offer and can bid for the deposit during a pre-specified time period, which is usually limited to two minutes and is initially set by each firm. Until the end of this period, a firm can select a bid based on its preferences. Banks do not observe other banks' bids but can adjust their offer during the bidding period. This implies that banks adjust their pricing during the bidding process only idiosyncratically, not in response to other banks' bids. Interest rates are quoted on an actual/360-day count convention and transactions are settled on the same day. Appendix A3 shows an example of a deposit auction and how the bids are quoted. Our sample covers the January 2, 2006 to June 30, 2010 period.

Our sample includes executed deposit transactions with a maximum maturity of seven days that are between non-financial firms and banks during the January 2006 to June 2010 period. The maximum maturity is in line with the Eurosystem's regular open market operations as described above. We do not have specific information on individual firms on the platform but have a unique platform-specific identifier for each firm that allows us to distinguish between depositors. Bank competition is measured at the deposit platform level using the HerfindahlHirschman Index (HHI) and data from the previous week. The final sample includes 40,638 euro-denominated deposit transactions from 145 European firms to 43 European banks with access to the ECB facilities.

Our loan-level data are based on the universe of loan facilities in the LPC DealScan database during the January 2006 to June 2010 period. We drop all loans where we cannot match the borrower to the Chava-Roberts (DealScan-Compustat) link file. We collect annual financial statement information for all non-financial firms from Compustat and merge it (with

\footnotetext{
${ }^{3}$ The number is calculated as the average of the daily outstanding deposit amount of each bank on the platform using all trading days (including zeros). This average is divided by the bank's end of year current liabilities as reported on the balance sheet.
} 
a one-year lag) to each loan contract and require that loan spread, maturity, amount, performance pricing and secured versus unsecured status are available for all loans. We select the lead bank for each loan following Ivashina (2009) and exclude loans from banks that do not operate on the deposit trading platform during our sample period. Overall, our final loan sample includes 2,632 firm-bank loan facilities from 38 banks to 566 firms. ${ }^{4}$

To measure the amount of Central Bank Liquidity available in the banking system, we use the natural logarithm of the sum of the banks' daily current account and deposit facility holdings with the ECB, centered by their mean value in 2006 (the so-called "adjusted liquidity in the banking sector"). ${ }^{5}$ Annual bank characteristics are collected from Bankscope and matched (with a one-year lag) to each deposit and loan transaction. To measure bank risk, we use five-year CDS spreads from credit market analysis (CMA). Using an iterative procedure explained in more detail in Online Appendix A, we ensure that high-risk banks (High Bank Risk) have, on average, at least twice the spread of low-risk banks in each week. ${ }^{6}$ In this procedure, we use (on a weekly basis) the minimum CDS spread of banks rated A1 or below as threshold and classify banks with a higher spread as high-risk banks. To ensure that low- and high-risk banks are sufficiently different, we then iteratively decrease this threshold in steps of $0.5 \mathrm{bps}$ until the ratio of the average spread of low- and high-risk banks is at least two in each week.

\footnotetext{
${ }^{4}$ Appendix A2 includes a table showing how many loan observations are dropped during our matching procedure. We also provide a comparison of our sample with the overall sample of European firms. We find that loan spreads are, on average, not significantly different between both samples. Our sample firms are larger both in terms of total assets and loan facility size, have more leverage and lower interest coverage, and also have more tangible assets as they are arguably more mature firms.

${ }^{5} \mathrm{We}$ also use other measures for central bank liquidity. A description of these measures for central bank liquidity in the banking sector is provided in Online Appendix A. We also perform all our analyses with these other measures but do not report them for brevity. All results remain robust.

${ }^{6}$ In addition to bank CDS spreads, we also use banks' Moody's long-term issuer credit rating as a measure of credit risk. Importantly, using either method, banks change their risk classification very infrequently. In unreported robustness checks, we exclude all banks that migrate between risk classes during the full-allotment period and rerun our regressions. In a different test, we use CDS spreads before the start of the financial crisis (August 9, 2007) to distinguish between high- and low-risk banks. The results remain unchanged. We report the results in Online Appendix E.
} 


\subsection{Descriptive statistics}

Panel A of Figure 1 shows the time series of weekly central bank liquidity, Panel B the percentage excess amount of central bank liquidity above the reserve requirement (Excess Liquidity Ratio). Prior to the financial crisis, the ECB allotted liquidity to banks such that these were able to fulfill their reserve requirements with very limited excess holdings. This is intuitive given the low interest rate earned in the deposit facility, which, during normal times, gives banks incentives to lend out excess liquidity in the interbank market. After the start of the financial crisis, the ECB started a "frontloading" policy and allocated funds to the market in excess of the benchmark liquidity in the early maintenance period and again absorbed these gradually over this period (Eisenschmidt, Hirsch, and Linzert, 2009).

\section{[Figure 1 here]}

Figure 1 shows an increase in both amount and volatility of liquidity. The start of the full allotment of liquidity at a fixed rate resulted in a strong increase in aggregate central bank liquidity. On June 25, 2009, the ECB announced it would provide additional liquidity via longterm refinancing operations (LTRO) with a maturity of one year, which induced another surge in aggregate liquidity.

Table 1 reports descriptive statistics for our main variables during the pre-financial crisis period, the crisis period until full allotment, and the full-allotment period. All data are deflated with 2006 as the base year. During the financial crisis, central bank liquidity increased from $€ 35$ billion to $€ 183$ billion in the full-allotment period.

[Table 1 here]

The average deposit has a maturity of 1.86 days (Average Duration), with an annual Deposit Rate of 226.7 bps and an Average Notional Deposit Amount of a transaction of $€ 71$ million (Table 1 reports the $\log$ amount to facilitate interpretation of the regression coefficients). The average deposit amount appears to be quite inelastic during our sample period. The Deposit Spread is defined as the deposit interest rate of a transaction minus the 
risk-free interest rate; we use the marginal deposit facility of the ECB as the excess reserves that the banks built up were arguably the next best alternative for banks compared to corporate deposits. The average Deposit Spread is 51.41 bps. We use the ECB main refinancing rate and the ECB lending facility interest rate as alternative risk-free interest rates and show that all results are insensitive to the benchmark interest rate.

Deposit rates and spreads decrease sharply between the pre-full-allotment and the fullallotment period. Loan spreads (AISD), on average, are $183 \mathrm{bps}$. The spreads increased substantially during the financial crisis. Loan maturities (Maturity in Months) and loan amounts (Facility Size), on the other hand, substantially shortened. The average loan matures in 54 months and is $€ 799$ million in size during our sample period. ${ }^{7}$

\subsection{Interest rates}

Panel A of Figure 2 depicts the development of the deposit facility, the marginal lending facility (MRO), and the short-term corporate deposit rates over the 2006 to mid-2010 period. Prior to the financial crisis, the deposit rate was anchored to the MRO. The figure shows that a functioning interbank market, together with tender operations with limited allotment, allowed banks to actively manage their liquidity, as well as the ECB to steer corporate deposit rates close to the MRO.

[Figure 2 here]

Although deposit rates became more volatile at the onset of the financial crisis, the corporate deposit rate remained close to the main refinancing rate. However, with the introduction of the ECB's full-allotment policy, the deposit rate dropped sharply, moving more closely to the ECB deposit facility interest rate as a direct effect of excess liquidity in the banking system. Panel B of Figure 2 shows the strong negative relation between corporate deposit spreads and aggregate liquidity. Overall, Figure 2 provides the first evidence that

\footnotetext{
${ }^{7}$ The total daily volume on the deposit platform is $€ 3,080$ million and the average daily volume of loans is $€ 5,370$ million, calculated using all trading days and including days with no observations as zeros.
} 
monetary policy expansion lowers short-term corporate deposit spreads in financial crises—an effect difficult to identify in normal times.

Panel A of Figure 3 shows the average CDS spread differential between high- and lowrisk banks. CDS spreads strongly increased at the start of the financial crisis for high- and lowrisk banks and remained at elevated levels, especially for high-risk banks, until June 2010. Prior to (after) the full allotment period around two thirds (half) of our sample banks are classified as low-risk banks. Panel B shows that deposit spreads decrease during the full-allotment period, particularly for the low-risk banks. Panel C shows that low-risk banks charge lower loan spreads than high-risk banks in the full-allotment period, which suggests that the transmission of monetary policy to the loan market might be impaired.

[Figure 3 here]

\section{Monetary policy and corporate deposits}

\subsection{Transmission of central bank liquidity to corporate deposit spreads}

We first investigate how aggregate central bank liquidity affects corporate deposits using the following regression model:

$$
\text { Deposit Spread }_{i j t_{w}}=a_{i}+a_{t_{m}}+\beta \text { Central Bank Liquidity } t_{w}+\theta^{\prime} Y_{j t_{y}-1}+\varepsilon_{i j t_{w}}
$$

where the dependent variable is the average corporate deposit spread paid by bank $j$ to firm $i$ in week $t_{w}$ (i.e. our data is at the bank-firm-week level) and the main inference variable is the contemporaneous weekly Central Bank Liquidity measure. $Y$ is a set of bank and deposit characteristics that might determine deposit spreads. Among our bank characteristics are bank total assets as well as different proxies for bank size, capitalization, profitability, asset quality and liquidity. ${ }^{8}$ These variables enter our regression with a one-year lag. We also include the

\footnotetext{
${ }^{8}$ These include a leverage ratio (as a proxy for capital adequacy), liquid assets over short-term funding, total deposits over total assets and net loans over customer deposits (as proxies for liquidity), net interest margin, costincome-ratio and return on assets (as proxies for profitability), and non-performing loans over total loans (as a proxy for asset quality). We also include the natural logarithm of banks' total assets, asset growth, off-balance-
} 
weekly notional deposit amount (Log(Notional Deposit Amount)) and a Herfindahl-Hirschman Index (HHI), calculated as the sum of the squared market share of each bank over the last week using deposit volume as a measure of bank competition. Market risk is measured using the three-month EURIBOR-EONIA swap spread. We include a firm fixed effect $\left(a_{i}\right)$ to observe the time-series effect of ECB liquidity on deposit spreads. As the average level of deposit spreads (and ECB liquidity) vary substantially over time, we also include a time (year-month) fixed effect $\left(a_{t_{m}}\right)$ such that the effect of ECB liquidity on deposit spreads is not moderated by the time effect. We analyze deposit transactions for the January 2, 2006 to June 30, 2010 period (column (1) of Table 2) and differentiate (in columns (2) to (4) of Table 2) between the prefinancial crisis period (January 2, 2006 to August 8, 2007), the financial crisis until fullallotment period (August 9, 2007 to October 7, 2008), and the full-allotment period (October 8, 2008 to June 30, 2010). Standard errors are clustered at the bank and week level using the methods in Cameron, Gelbach and Miller (2011) and Thompson (2011). We estimate equation (1) using OLS; Table 2 reports the results.

\section{[Table 2 here]}

The results in column (1) of Table 2 show that an increase in central bank liquidity results in lower corporate deposit spreads, but only during the financial crisis period (columns (2)-(4)). A one standard deviation increase in central bank liquidity reduces deposit spreads by about $3 \mathrm{bps}$ in the financial crisis until the full-allotment period and by about $8 \mathrm{bps}$ in the fullallotment period. ${ }^{9}$ The coefficient of $\log$ (Notional Deposit Amount) is negative and significant, particularly during the financial crisis period, i.e. if the weekly provision of deposits is higher, then the deposit spread is lower. The remaining control variables remain unreported for brevity but a full set of results is documented in Online Appendix C.

\footnotetext{
sheet exposure over total assets, and net derivatives exposure over total assets as additional control variables. The variables are defined in Appendix A1.

${ }^{9}$ The numbers are calculated by multiplying the coefficient with one standard deviation of central bank liquidity. The latter is 0.129 in the crisis period until full allotment and 0.275 in the full-allotment policy period.
} 


\subsection{Transmission of monetary policy to high-versus low-risk banks}

The results in the previous subsection are consistent with the interpretation that the ECB reduced the funding risk of banks during the financial crisis: a higher amount of central bank liquidity decreases corporate deposit spreads. In this subsection, we analyze possible differences in the transmission of central bank liquidity in the cross section for low- versus high-risk banks and augment equation (1) to estimate individual $\beta^{\prime}$ s for low- and high-risk banks.

$$
\begin{gathered}
\text { Deposit Spread }_{i j t_{w}}=a_{i j}+a_{j t_{m}}+a_{i t_{m}}+\beta \text { Risk }_{j} \times \text { Central Bank Liquidity }_{t_{w}}+\theta^{Y_{j t_{y}-1}} \\
+\varepsilon_{i j t_{w}}
\end{gathered}
$$

We interact Risk, an indicator variable representing either High Bank Risk or Low Bank Risk, with Central Bank Liquidity, to investigate the effect of central bank liquidity during the financial crisis. In different specifications, we further include firm x year-month fixed effects $\left(a_{i t_{m}}\right)$, bank x year-month fixed effects $\left(a_{j t_{m}}\right)$, and bank x firm fixed effects $\left(\mathrm{a}_{\mathrm{ij}}\right)$. The model is estimated via OLS.

Our empirical approach provides an unbiased estimate of the effect of central bank liquidity on deposit spreads only if central bank liquidity is exogenously determined, which might be a strong assumption. Central bank liquidity might respond to the availability of interbank, corporate or retail deposits for banks. Moreover, other unobserved factors that differentially affect deposit spreads of high- versus low-risk banks might be correlated with the ECB's supply of liquidity. For example, the ECB might increase liquidity in a situation in which we observe a flight-to-quality from depositors who shift deposits from high- to low-risk banks. ${ }^{10}$ Similarly, high-risk banks might have high-risk customers whose credit quality further deteriorates when economic conditions worsen, adversely affecting the risk of their respective

\footnotetext{
${ }^{10}$ Strong banks might even bid strategically in central bank tenders (Fecht, Nyborg, and Rocholl, 2011; Cassola, Hortacsu, and Kastl, 2013) and deliberately under-provide lending to weaker banks (Acharya, Gromb, and Yorulmazer, 2012).
} 
bank; the latter, in turn, might need to increase deposit spreads even further to obtain funding. In these situations, our coefficients might be biased.

In a first step, we sequentially add control variables and fixed effects and compare the coefficient of our endogenous variable (Central Bank Liquidity $\times$ Risk) across different specifications. Panel A of Table 3 reports the result for the crisis until the full-allotment period.

\section{[Table 3 here]}

Column (1) shows the results without any control variables or fixed effects. We add bank risk x time (year-month) fixed effects in column (2) to control for specific shocks to highand low-risk banks in a given month that affect both central bank liquidity provision as well as deposit spreads and further include firm fixed effects, as firms might differentially price deposits for high- and low-risk banks. We add bank x time (year-month) fixed effects in column (3) to account for the fact that shocks might occur not (only) at the bank-risk but also at the bank level. In column (4), we add firm x time (year-month) and firm x bank fixed effects, which proxy for the supply of deposits by firms and a possible match of firms with banks. ${ }^{11}$

The coefficient of Central Bank Liquidity $\times$ Low Bank Risk is negative and economically and statistically significant and even somewhat increases in magnitude across all specifications. The coefficient of Central Bank Liquidity $\times$ High Bank Risk is insignificantly different from zero across all specifications. A Wald test under the null hypothesis that these coefficients are equivalent is rejected at the $1 \%$ significance level. In other words, we observe a differential effect of central bank liquidity on deposit spreads of high- versus low-risk banks in the financial crisis before the full-allotment period.

In Panel B of Table 3 we repeat these tests for observations during the full-allotment period. In the specification without any control variables, we show that central bank liquidity reduces deposit spreads for both high- and low-risk banks (and the coefficients are

\footnotetext{
${ }^{11}$ We provide a formal test of matching of firms with banks in individual deposit auctions (i.e. on a transaction level) in Online Appendix D3.
} 
insignificantly different). This result extends to all specifications. Notably, central bank liquidity alone explains about $22 \%$ of the variation in corporate deposit spreads. We then add our different fixed effects as described above. The change of the coefficient of our interaction terms is small across specifications and the adjusted $\mathrm{R}^{2}$ already increases to 0.83 when saturating the model. That is, any effect of unobservable factors that we cannot control for has to be large per (remaining) $\mathrm{R}^{2}$ to reduce the coefficient to zero (Altonji et al., 2005; Oster, 2019).

What explains the differential transmission of aggregate liquidity on deposit spreads before the ECB implemented the full-allotment framework, and what changed afterwards? At the beginning of the financial crisis, credit market shocks transmitted into funding markets that became increasingly stressed. Banks started hoarding liquidity as a precautionary measure to ensure the availability of liquidity for day-to-day operations (Heider et al., 2015). Aggregate liquidity, in turn, was insufficiently distributed in the interbank market. At that time, the ECB only allocated enough aggregate liquidity for banks to fulfill their reserve requirements. Our deposit spread differential evidence suggests that central bank liquidity during this phase was insufficient to reduce funding risk of both low- and high-risk banks. ${ }^{12}$ High-risk banks needed to pay substantially higher deposit spreads to compensate depositors and attract funds. The differential effect of ECB liquidity on deposit spreads dissipated after the ECB stepped in as a LOLR and introduced its full-allotment policy, allotting liquidity as requested by European banks in full. ${ }^{13}$

\subsection{Tracing out corporate deposit demand}

Our approach so far does not allow us to clearly isolate the effect of central bank liquidity on

\footnotetext{
12 The Bank for International Settlements (BIS) even reports that borrowing from a central bank might have been a stigma elevating funding problems of high-risk banks even further.

${ }^{13}$ Our results do not imply a reduction in market discipline due to ECB liquidity provision. In unreported tests, we show that the deposit spread differential between high- and low-risk bank does not change when liquidity increases. Overall, the evidence shown in this paper suggests that the deposit market is not characterized by market discipline and that bank risk is not priced in corporate deposits.
} 
banks' demand for corporate deposits. We next use a system of three equations to trace out the deposit demand curve, which requires instruments that shift central bank liquidity as well instruments that shift the corporate supply of deposits that are orthogonal to banks' demand for deposits. In all specifications, the unit of observations is a bank-firm-week. All specifications use the same set of control variables as in column (4) of Table 3, and we add shifters for central bank liquidity and firms' supply of deposits to estimate the coefficients of the deposit demand equation. We describe the provision of central bank liquidity in equation (3):

$$
\begin{gathered}
\text { Central Bank Liquidity } \text { Lijt }_{w}=a_{i j}+a_{j t_{y}}+a_{i t_{y}}+\beta^{\prime} X_{t_{w}} \\
+\delta \text { End of Reserve Maintenance Period } t_{w}+\theta^{\prime} Y_{j t_{y}-1}+\varepsilon_{i j t_{w}}
\end{gathered}
$$

End of Reserve Maintenance Period is our instrument to shift central bank liquidity. During the full-allotment period, the ECB provides the amount of liquidity as requested by banks. Banks know the start and end date of each maintenance period and a bank's reserve requirement is determined as an average over this period, which is usually one month. Furthermore, at the height of a financial crisis, banks either demand liquidity or, if they have already fulfilled their reserve requirements, hoard liquidity (Acharya and Merrouche, 2013). The identifying assumption is that demand for central bank liquidity at the end of the maintenance period is determined by a bank's reserve requirement, which is unrelated to deposit spreads. In other words, End of Reserve Maintenance Period is defined as the week in which the maintenance period ends.

$X$ is a vector of funding sources: interbank lending, retail and corporate deposits. Similar to central bank liquidity, we use the log of the notional amounts, centered around their 2006 means. We obtain the data from the ECB website for interbank and retail deposits and use the weekly total volume of deposits traded on the platform as our measure for corporate 
deposits. ${ }^{14}$ The ECB provides aggregate data on retail and interbank funds on a monthly basis. Equation (4) estimates firms' supply of deposits:

$$
\begin{aligned}
& \log (\text { Notional Deposit Amount })_{i j t_{w}}=a_{i j}+a_{j t_{y}}+a_{i t_{y}}+\beta \text { Ris }_{j} \times \text { Central Bank } \text { Liquidity }_{t_{w}} \\
& \quad+\delta \text { Excess Cash }_{t_{q}}+\gamma \text { Deposit Spread } \\
& \text { Set }_{w}
\end{aligned}
$$

where Excess Cash is a continuous measure of firms' aggregate quarterly excess cash holdings. Ideally, we need an exogenous shock to a firm's cash holdings (e.g. a tax refund). We do not know the identities of firms or their industries in our sample. We thus require a time-varying shock to aggregate cash holdings to firms that is orthogonal to banks' demand for deposits. As an alternative identification strategy, we incorporate excess cash holdings as an instrument. The identifying assumption is that firms' aggregate excess cash holdings, which are measured quarterly across all EU firms using variation across time, industries and countries, are orthogonal to banks' demand for deposits. We derive this measure formally in Appendix $4 .{ }^{15}$

With equation (5), we identify banks' demand for corporate deposits:

$$
\begin{aligned}
& \text { Deposit Spread }_{\text {ijt }_{w}} \\
& =a_{i j}+a_{j t_{y}}+a_{i t_{y}}+\beta \text { Risk }_{j} \times \text { Central Bank } \text { Lıquıd } t \text { ty }_{t_{w}} \\
& +\gamma \log (\text { Notıonal } \widehat{D e p o s i t} \text { Amount })_{i j t_{w}}+\theta^{\prime} Y_{j t_{y-1}}+\varepsilon_{i j t_{w}}
\end{aligned}
$$

The instruments that shift central bank liquidity and the supply of deposits allow us to estimate the parameters of the demand curve. We estimate a system of equations via GMM with observations in the full-allotment period similar to Röller and Waverman (2001) to impose more structure on our data. We thereby account for simultaneity between deposit spreads,

\footnotetext{
${ }^{14}$ In unreported robustness tests, we also use the volume of corporate deposits from the ECB. The results are very comparable.

${ }^{15}$ We also construct an indicator variable that is 1 if excess cash exceeds a long-run mean. As a third instrument, we use an indicator variable Fourth Quarter of the Year that is 1 in the last three months of each year. Firms might be more likely to deposit additional funds during periods that include several public holidays instead of, for example, keeping them as cash for operational purposes. All tests using the different instruments give similar results. We also estimate the system of equations using transaction-level data and a dummy variable for Friday as an instrument. We provide all results in Online Appendix D4.
} 
deposit amount and central bank liquidity and are able to trace out the deposit demand function. This approach is more efficient than 2SLS (e.g. Cornwell et al., 1992; or Ashenfelter and Rouse, 1998). However, others have voiced concern with this approach given potential finite-sample problems of GMM (e.g. Tauchen, 1986; Kocherlakota, 1990; or Hansen et al., 1996). We thus compare the coefficients from this model with the OLS estimates from Table 3 when interpreting our results.

[Table 4 here]

Column (1) of Table 4 shows the results from equation (3). The coefficient of the instrument is negative and significant. ECB liquidity is lower at the end of the maintenance period, suggesting that banks have, on average, already fulfilled their reserve requirements in the last week of the maintenance period and require less central bank liquidity. Central bank liquidity is negatively related to interbank lending, but positively related to retail and corporate deposits. A possible explanation is the stress in interbank markets as well as the flight of retail and corporate customers to (supposedly safe) liquidity, after numerous interventions in the banking sector.

Column (2) shows the results from equation (4) and provides coefficient estimates of the supply curve for corporate deposits during the full-allotment period. The coefficient of our instrument (Excess Cash) is, as expected, positive and significant. Firms have more cash to deposit in quarters where firms, on average, hold more excess cash. Consistent with our results in column (1), central bank liquidity (for both high- and low-risk banks) is positively correlated with the supply of corporate deposits. The coefficient of Deposit Spread is also positive and significant showing that-holding everything else constant—firms supply more deposits if banks are willing to pay higher spreads. In other words, liquidity-constrained banks can access more corporate deposit funding by offering higher spreads. This is an important result as it highlights the importance of the corporate deposit market for banks, even in the full-allotment period. The magnitude of the coefficient, however, is small suggesting that the supply of 
corporate deposits is relatively inelastic with respect to the deposit spread.

The third column provides coefficient estimates of the deposit demand curve. The coefficient of $\log$ (Notional Deposit Amount) is negative with respect to deposit spreads. That is, if the weekly provision of deposits is higher, then the marginal utility of having deposits is lower, which decreases its opportunity cost, i.e. the deposit spread. The coefficient is both statistically and economically meaningful. A one standard deviation increase in Log(Notional Deposit Amount $)$ decreases deposit spreads by about 1 bps $(=-0.655 \times 1.5)$, which is $5 \%$ of the standard deviation of deposits spreads (and a quarter of the average deposit spread during this period).

The coefficients of the interaction terms of central bank liquidity and high and low bank risk are negative and significant but there is no differential effect of central bank liquidity of high- versus low-risk banks on deposit spreads as the Wald test suggests. That is, an increase in central bank liquidity shifts the deposit demand curve inwards and both high- and low-risk banks are only willing to pay less for corporate deposits, all else equal. The coefficient estimates are (in absolute terms) somewhat lower compared to our OLS estimates. A one standard deviation increase in central bank liquidity reduces deposit spreads by about 6 bps. However, the coefficient estimates between both specifications are still close and they are both consistent with the same narrative: the central bank provides sufficient liquidity that it reduces the equilibrium price for corporate deposits. That is, monetary policy transmits through a demand channel, reducing deposit spreads for depositors of both high- and low-risk banks.

\section{Monetary policy and corporate loans}

To investigate whether the transmission channel of monetary policy to the corporate loan market is impaired, we analyze whether low- and high-risk banks pass along their lower funding costs to their corporate clients during the full-allotment period. We match banks from the corporate deposit data set to banks in DealScan and compare their lending and deposit-taking behavior. 


\subsection{Transmission of central bank liquidity to corporate loan spreads by bank risk}

We first investigate the impact of central bank liquidity on corporate loan spreads using an empirical set-up that is comparable to our prior analysis of corporate deposit rates in Section 5. We use an average of the ECB liquidity over a three-month period prior to loan origination as a measure of central bank liquidity. ${ }^{16} \mathrm{We}$ control for different borrower characteristics that have been shown to affect loan pricing such as total assets, leverage, current ratio, interest coverage, market-to-book ratio and the percentage of tangible assets relative to total assets. We also include bank-specific controls (such as total assets, asset growth, leverage, return on assets and non-performing loans). Bank and borrower characteristics are lagged by one year. Additionally, we control - at the transaction level—for loan size and maturity, the number of previous loans of the borrower, whether the loan is secured and contains a performance pricing grid, and market risk (three-month EURIBOR-EONIA swap spread). To improve our estimates and address the possible endogeneity of central bank liquidity to the business cycle, we further include (at quarterly frequency) GDP growth in the eurozone, the Composite Indicator of Systemic Stress (CISS) and the main refinancing rate (which we refer to combined as "Macro Environment" in the tables). All variables are described in detail in Appendix A1 but remain unreported for brevity. All models also include loan purpose, loan type, borrower industry, borrower rating and loan currency fixed effects. Standard errors are clustered at the borrower level. We use the following regression specification:

$$
A I S D_{i j k}=a_{\text {Risk }_{j} t_{y}}+\beta \text { Risk }_{j} \times \text { Central Bank Liquidity } t_{q-1}+\theta^{\prime} Y_{j t-1}+\varepsilon_{i j k}
$$

where the dependent variable is the all-in-spread-drawn (AISD) of loan $k$ from bank $j$ to firm $i$ (i.e. our unit of observation is the loan transaction). We interact Ris $_{j}$, an indicator variable representing either High Bank Risk or Low Bank Risk, with Central Bank Liquidity to

\footnotetext{
${ }^{16}$ Loan negotiations take time to unfold before the loan contract is signed. Alternatively, we also use the average of central bank liquidity over the week and the month prior to loan origination. The results do not change and are unreported for brevity.
} 
investigate the effect of average central bank liquidity over the previous quarter on loan spreads. $Y_{j t-1}$ is a vector of lagged bank, firm and loan characteristics as well as other controls described above. $a_{R i s k_{j} t_{y}}$ are bank-risk x year fixed effects to control for effects on loan spreads that are specific to either high- or low-risk banks and that might vary annually. Table 5 shows the results of pooled OLS regressions using the AISD as the dependent variable during the financial crisis period. ${ }^{17}$

Panel A (Panel B) of Table 5 shows the results without (with) control variables and fixed effects. Comparing the coefficients with and without control variables and the respective impact on the $\mathrm{R}^{2}$ helps to further address endogeneity concerns that monetary conditions might bias our point estimates, particularly during the full-allotment period, when liquidity conditions were improved by the ECB. Unobserved factors that increase loan spreads could be positively correlated with the ECB's supply of liquidity, suggesting that we might overestimate the effect from the liquidity provision (Altonji et al., 2005; Oster, 2019). Standard errors are clustered at the firm and at the week level using the methods in Cameron, Gelbach and Miller (2011) and Thompson (2011).

[Table 5 here]

The results in column (1) of both Panel A and Panel B of Table 5 show that an increase in central bank liquidity reduces loan spreads. Again, we find a differential effect for highversus low-risk banks (column (2)): while low-risk banks reduce loan spreads, the interaction term with high-risk banks does not enter significantly into the regression. When we split the overall sample into the financial crisis until the full-allotment period and the full-allotment period, we find that an increase in central bank liquidity reduces loan spreads only when loans are issued by low-risk banks, but not by high-risk banks in the full-allotment period (columns (3)-(6)).

\footnotetext{
${ }^{17}$ We do not report the results for the pre-crisis period as we focus on monetary policy during the financial crisis. In the pre-crisis period, we do not find a statistically or economically significant effect of central bank liquidity on loan spreads for neither the low- nor high-risk banks.
} 
Comparing the coefficients in Panel A and Panel B of Table 5 shows that our point estimate during the financial crisis period even decreases when we include control variables and fixed effects (column (1)). During the full-allotment period, the coefficient somewhat increases to -164 bps (column (6)) but remains both economically and statistically highly significant. That is, loan spreads decrease by 27 bps when central bank liquidity increases by one standard deviation $(=-164 \times 0.166)$. These estimates are thus likely in the upper bounds of the true effect of central bank liquidity on loan spreads. Importantly, the adjusted $\mathrm{R}^{2}$ increases from 0.04 to 0.74 in Column (6), i.e. any effect of an unobservable factor per (remaining) $\mathrm{R}^{2}$ has to be even larger (Altonji et al. 2005; Oster, 2019) such that the effect of central bank liquidity becomes zero.

Overall, and as our introductory quote suggests, monetary policy transmission during periods of unconventional and expansive monetary policy depends on the stability of the banking system: monetary policy might not transmit to the real sector if there are substantial differences in bank balance-sheet strength across the euro area. ${ }^{18}$

\subsection{Intensive versus extensive margin}

\subsubsection{Heckman selection model}

A possible concern with our results might be that poorly capitalized banks charge higher interest rates due to a matching of weak borrowers with weak banks during the full-allotment period. We thus investigate the loan spreads of borrowers who borrow from the same group of either low- or high-risk banks before and after the full-allotment period (intensive margin), as well as the likelihood that firms switch to a new group of lenders during the full-allotment period (extensive margin).

We regress an indicator variable, which is 1 if the borrower does not switch between risk groups and 0 otherwise, on borrower, bank, and other control variables as explained above.

\footnotetext{
${ }^{18}$ We focus on differences between the health of lead arrangers to gain an understanding of the transmission of monetary policy. In unreported tests, we show that the presence of better capitalized banks in a lending syndicate where the lead bank is weak somewhat increases the pass-through of monetary policy.
} 
If firms and banks match only on quality, we would expect bank risk and other bank characteristics to be different between borrowers who switch or do not switch banks. We use an OLS, a probit, and a logit model without fixed effects, as well as an OLS model with bank, time, bank risk-time, borrower industry and rating, and loan type, loan purpose, and loan currency fixed effects.

\section{[Table 6 here]}

The results in Panel A of Table 6 shows that bank characteristics and bank risk are not correlated with the firms' decisions to switch between bank risk groups. Neither our bank risk indicator variable nor any of the banks' characteristics are usually statistically significant.

We next investigate the effect of central bank liquidity on the loan spreads of borrowers who do not switch between bank risk groups before and during the full-allotment period. Column (1) of Panel B of Table 6 shows a pooled OLS regression model, while column (2) reports the results of a Heckman selection model using the model employed for the results in column (3) of Panel A of Table 6 as the first stage. The regression results confirm our earlier results. In both models, an increase in central bank liquidity translates into lower loan spreads for borrowers of low-risk banks also when we account for borrower-lender matching. The coefficient for high-risk banks is insignificant in both specifications. The Wald test, under the null hypothesis that the coefficients of the interaction terms are identical, can be rejected at the $5 \%$ level in both models. Thus, an increase in central bank liquidity reduces the loan spreads of the borrowers of low-risk banks more, relative to high-risk banks in the full-allotment period.

\subsubsection{Propensity score matching}

To ensure that these results are not driven by differences in borrower risk between high- and low-risk banks, we use different propensity score matching (PSM) models: nearest neighbor matching with 10, 50, and 100 neighbors and kernel matching using both the Gaussian and the 
Epanechnikov kernel. ${ }^{19}$ We restrict the match of neighbors for the nearest neighbor matching to a caliper of 0.1 and for the kernel matching to a bandwidth of 0.01 and use bootstrapped standard errors.

[Table 7 here]

The results in Panel A of Table 7 show that in the full-allotment period, high-risk banks' borrowers pay, on average, 120 bps more when using the nearest neighbor matching methods and 100 bps more than low-risk banks' borrowers when we use the kernel matching methods and. This difference is usually significant at the $1 \%$ level.

We then focus on borrowers matched via PSM in multivariate regressions. For both the nearest neighbor and the kernel matching, we use the nearest match to each treated firm within the defined caliper or bandwidth $(n=1)$. Panel B of Table 7 shows the results of regressions of loan spreads on bank risk, central bank liquidity and bank control variables. We find that central bank liquidity only reduces the loan interest rates of low-risk banks in the full-allotment period. In Online Appendix G, we show that size, leverage, and current ratio are significantly correlated with bank risk. We thus add interaction terms of these variables with central bank liquidity using all loans issued in the full-allotment period to address further concerns that our results are driven by riskier borrowers that are more affected by expansive monetary policy (Bernanke and Gertler, 1995). The results are reported in Panel C of Table. The evidence reinforces our earlier result that the loan-spread differential reflects an impaired transmission of monetary policy because the banking system is weak.

\section{Monetary policy transmission and the real economy}

\subsection{Monetary policy and loan maturity}

While the ECB targets the short end of the yield curve, investments are long-term decisions and dependent on the availability of funding liquidity at longer maturities. If the transmission

\footnotetext{
${ }^{19}$ We match borrowers in the full-allotment period based on total assets, leverage, current ratio, coverage, marketto-book ratio, tangibility, year, borrower industry code, borrower rating, loan type, loan purpose, loan currency, loan maturity, secured, loan amount, performance pricing, and the number of previous loans.
} 
channel is impaired, we expect to see loan-spread differences between high- and low-risk banks, particularly for long-maturity loans. We differentiate between short-, medium-, and long-term loans, which have maturities of less than or equal to one year, one to five years or more than five years, respectively, and report the results in Panel A of Table 8 for the full-allotment period.

[Table 8 here]

High- and low-risk banks reduce interest rates on short-term loans when central bank liquidity increases during the full-allotment period. Wald tests suggest that the reduction is not significantly different between both bank risk groups. In contrast, low-risk banks require significantly lower interest rates for medium-term loans than high-risk banks when central bank liquidity increases. Moreover, lower economic significance for medium- relative to short-term loans of low-risk banks suggest that the ECB needs longer-term liquidity to influence long-term loans-importantly, however, this is true after financial stability has been restored. Elevated loan spreads for medium-term maturities could suggest that high-risk banks are reaching for yield. We thus run our regressions only on the intensive margin (column (3)). In column (4), we further include interaction terms of central bank liquidity with borrower size, leverage and current ratio as in Table 7 to entertain the possibility that our results reflect high-risk banks reaching for yield. Our results remain qualitatively unchanged. Overall, we find that short-term liquidity provision by the ECB has an effect in both deposit and loan markets for maturities below one year, but not for medium- and long-term maturities, for which the transmission channel is impaired.

\subsection{Borrower financial constraints}

What frictions prevent borrowers from switching from high- to low-risk banks if borrowing at high-risk banks is more expensive? A plausible explanation is that borrowers are financially constrained and thus cannot easily substitute external financing from weak banks. As in Fazzari, Hubbard and Petersen (1988), Gertler and Gilchrist (1994) or Kashyap, Lamont and Stein (1994), we use firm size or the availability of debt ratings (from S\&P) as proxies for borrowers' 
financial constraints and reliance on external funding. We classify firms as small, medium and large using the 33rd and 67th percentile of total assets of all firms in the data sample.

In Panel B of Table 8, we find that the transmission of central bank liquidity is impaired for bank-dependent firms at high-risk banks. High-risk banks do not reduce the loan spreads for small- and medium-sized firms as well as for firms without a public debt rating, even when central bank liquidity increases. In contrast, both high- and low-risk banks require lower loan spreads from large firms and from firms with a public debt rating, when central bank liquidity increases.

\subsection{Investment and financing decisions}

Financing constraints of high-risk bank borrowers might affect their investment and financing decisions (Chodorow-Reich, 2014). We collect capital structure data from Capital IQ (term loans, revolving loans and notional amount of debt outstanding) and investment variables from Compustat (liabilities, payouts, capital expenditures, asset growth, investments, and number of employees) for the 2005-2013 period. Our focus is on borrowers from either a low- or a highrisk bank before and after the full allotment, which we match using PSM. We then regress changes in firm characteristics on High Bank Risk using the PSM sample over a period of one $(t+1)$, two $(t+2)$, and three years $(t+3)$ after a firm received a loan in the full-allotment period and report the results in Table $9 .{ }^{20}$ For brevity, we only report the coefficient of High Bank Risk.

[Table 9 here]

We find that, relative to borrowers from low-risk banks, the percentage of term loans of high-risk bank borrowers decreases by about six percentage points in the third year after loan issuance, while the percentage of revolving loans increases by 5.5 percentage points. This result is intuitive. The ECB provides high-risk banks with sufficient liquidity to become a credible

\footnotetext{
${ }^{20} \mathrm{We}$ also investigate these changes for one, two, and three years before a firm has received a loan in the fullallotment period to check the parallel trend assumption. Our results show that the characteristics of high-risk bank borrowers develop comparably to those of low-risk bank borrowers prior to obtaining a loan during the fullallotment period.
} 
liquidity provider for borrowers. Consistently, we do not find evidence that high-risk bank borrowers draw down their credit lines more than low-risk bank borrowers, suggesting that the result is due to a change in the supply of credit by banks.

We also find somewhat negative effects on investment and employment of firms borrowing from high-risk banks. In years two and three after loan origination in the fullallotment period, payouts, capital expenditures, investments and employment are all lower for high-risk bank borrowers compared to that of low-risk bank borrowers. Lawrence et al. (2005) argue that after a monetary policy shock, corporate real investment may have a lagged response function. Our results, however, are only significant at the $5 \%$ or $10 \%$ level. A possible explanation might be the number of large firms in our sample, who are less financially constrained.

\section{Conclusion}

Banking sector weakness can impair the transmission of monetary policy. Using deposit and loan transaction data for Europe during the period from January 2006 to June 2010, we document that an increase in ECB liquidity up to levels demanded by banks ("full allotment") results in (i) the same decrease of deposit spreads for low- and high-risk banks, and (ii) a reduction of loan spreads charged by low-risk banks, but (iii) has almost no effect on the loan spreads of high-risk banks. While borrowers of high-risk banks increase their credit lines relative to their term-loan borrowing following the liquidity provision by the ECB, these firms also invest less, have lower capital expenditures and reduce the number of employees.

Our results are consistent with high-risk banks not passing on funding cost advantages to their borrowers. With the ability to charge higher loan spreads from bank-dependent customers, they might benefit from an increase in central bank liquidity by not passing on their lower funding costs, which increases their net worth and relaxes both regulatory and economic constraints (Brunnermeier and Sannikov, 2016, and Brunnermeier and Koby, 2019). An alternative view is that high-risk banks are reaching for yield. Our previous tests show that 
riskier borrowers do not switch to high-risk banks during the full-allotment period (extensive margin) and we observe the main results on the intensive margin. However, also on the intensive margin, risk-shifting of high-risk banks can occur as a consequence of high-risk banks not passing on lower funding costs to borrowers. That is, keeping interest rates higher might make firms endogenously riskier. Thus, on the intensive margin, our results are also consistent with a reaching-for-yield interpretation.

The ECB's introduction of the full allotment in October 2008 was also a reaction to banks' liquidity problems in the interbank market. Prior research has largely ignored problems in funding markets, focusing exclusively on the transmission to the real economy via loan markets. However, an impaired transmission channel might originate because funding markets are stressed and the design and the effectiveness of monetary policy measures might therefore crucially depend on both markets.

Thus, it is an important question whether the transmission of monetary policy to the real economy is impaired even after the ECB has addressed the problems in the funding market. Our results suggest that the ECB has indeed addressed the funding problems with the introduction of the full allotment. However, we also find evidence that the transmission channel of monetary policy in the euro area is still impaired in the loan market, which is consistent with the view that banking sector balance-sheet weakness limited the role of the ECB as LOLR during the financial crisis. In other words, we have to look at both the deposit and the loan market to separate whether bank balance-sheet effects are at work, even after the ECB has addressed the funding problems of banks. The deposit data are key as they highlight that even when funding conditions are restored to the same level by the ECB for low-risk and high-risk banks, the loan outcomes are not highlighting a divergence between liquidity- and solvencyinduced outcomes for banks.

Overall, our results suggest that banks' capital constraints at the time of an easing of monetary policy pose a challenge to the effectiveness of the bank-lending channel and the 
effectiveness of the central bank as a lender of last resort. These results have potentially important implications for other (unconventional) monetary policy measures in the eurozone such as the long-term refinancing operations (LTRO), which were also undertaken in the presence of relatively weak bank balance sheets. Finally, while we focused on large firms due to data availability constraints, the transmission of monetary policy by weak banks is likely to be even further restricted for financially constrained firms. This is worthy of further inquiry to understand the full economic magnitude of the effects we have unearthed. 


\section{References}

Acharya, Viral V., Denis Gromb, and Tanju Yorulmazer, 2012, Imperfect competition in the interbank market for liquidity as a rationale for central banking, American Economic Journal: Macroeconomics 4, 184-217.

Acharya, Viral V., and Ouarda Merrouche, 2013, Precautionary hoarding of liquidity and interbank markets: evidence from the subprime crisis, Review of Finance 17, 107-160.

Afonso, Gara, Anna Kovner, and Antoinette Schoar, 2011, Stressed, not frozen: the federal funds market in the financial crisis, Journal of Finance 66, 1109-1139.

Altonji, Joseph G., Todd E. Elder, and Christopher R. Taber, 2005, Selection on Observed and Unobserved Variables: Assessing the Effectiveness of Catholic Schools, Journal of Political Economy 113(1), 151-84.

Ashenfelter, Orley, and Cecilia Rouse, 1998, Income, Schooling, and Ability: Evidence from a New Sample of Identical Twins, The Quarterly Journal of Economics 113(1), 253-284.

Baum, Christopher F., Schaffer, Mark E., and Stillman, Steven, 2007, Enhanced routines for instrumental variables/GMM estimation and testing, Boston College Department of Economics Working Paper No. 667.

Bernanke, Ben S., 2007, The financial accelerator and the credit channel, in Federal Reserve Bank of Atlanta, Presented at the The Credit Channel of Monetary Policy in the Twenty-first Century Conference, Atlanta, Georgia.

Bernanke, Ben S., and Alan S. Blinder, 1988, Credit, money, and aggregate demand, The American Economic Review 78, 435-439.

Bernanke, Ben S., and Mark Gertler, 1989, Agency Costs, Net Worth and Business Fluctuations, American Economic Review 79, 14-31.

Bernanke, Ben S., and Mark Gertler, 1995, Inside the black box: The credit channel of monetary policy transmission, Journal of Economic Perspectives 9, 27-48. 
Brunnermeier, Markus K., and Yuliy Sannikov, 2016, The I Theory of Money, Working Paper, Princeton University.

Brunnermeier, Markus K, and Yann Koby, 2019, The reversal interest rate: The effective lower bound of monetary policy, Working Paper.

Cameron, A.C., J.B. Gelbach, and \& D.L. Miller, 2011, Robust Inference With Multiway Clustering, Journal of Business \& Economic Statistics Vol. 29(2).

Campello, Murillo, 2002. Internal capital markets in financial conglomerates: evidence from small bank responses to monetary policy. Journal of Finance 57, 2773-2805.

Cassola, Nuno, Ali Hortacsu, and Jakub Kastl, 2013, The 2007 subprime market crisis through the lens of European central bank auctions for short-term funds, Econometrica 81, 1309-1345.

Chodorow-Reich, Gabriel, 2014, The employment effects of credit market disruptions: Firmlevel evidence from the 2008-9 financial crisis, The Quarterly Journal of Economics 129, 159.

Cornwell, Christopher, Peter Schmidt, and Donald Wyhowski, 1992, Simultaneous equations and panel data, Journal of Econometrics 51, 151-181.

Dell'Ariccia, Giovanni, Luc Laeven, and Gustavo A. Suarez, 2017, Bank leverage and monetary policy's risk-taking channel: Evidence from the united states, The Journal of Finance 72, 613654.

Drechsler, Itamar, Alexy Savov, and Philipp Schnabl, 2017, The deposit channel of monetary policy, Quarterly Journal of Economics 132(4), 1819-1876.

Eisenschmidt, Jens, Astrid Hirsch, and Tobias Linzert, 2009, Bidding behaviour in the ECB's main refinancing operations during the financial crisis, Working Paper No. 1052, European Central Bank. 
Fazzari, Steven M., R. Glenn Hubbard, Bruce C. Petersen, 1988, Financing constraints and corporate investment, Brookings Papers on Economic Activity 1988, 141-206.

Fecht, Falko, Kjell G. Nyborg, and Jörg Rocholl, 2011, The price of liquidity: The effects of market conditions and bank characteristics, Journal of Financial Economics 102, 344-362.

Frésard, Laurent, and Carolina Salva, 2010, The Value of Excess Cash and Corporate Governance: Evidence from U.S. Cross-listings, Journal of Financial Economics 98, 359-384.

Gambacorta, Leonardo, Paolo E. Mistrulli, 2004. Does bank capital affect lending behavior? Journal of Financial Intermediation 13, 436-457.

Gertler, Mark, and Simon Gilchrist, 1994, Monetary policy, business cycles, and the behavior of small manufacturing firms, Quarterly Journal of Economics 109, 309-340.

Gomez, M., Landier, A., Sraer, D., Thesmar, D., 2016. Banks' exposure to interest rate risk and the transmission of monetary policy. Unpublished working paper. National Bureau of Economic Research.

Hansen, Lars Peter, John Heaton, and Amir Yaron, 1996. Finite-sample properties of some GMM models, Journal of Business and Economic Statistics 14(3), 262-280.

Heider, Florian, Marie Hoerova, and Cornelia Holthausen, 2015, Liquidity Hoarding and Interbank Market Spreads: The Role of Counterparty Risk, Journal of Financial Economics $118,336-354$.

Heider, Florian, Farzad Saidi, and Glenn Schepens, 2019, Life below zero: Bank lending under negative policy rates. Review of Financial Studies 32(1), 3728-3761.

Ioannidou, Vasso, Steven Ongena, and José-Luis Peydró, 2015, Monetary policy, risk-taking, and pricing: Evidence from a quasi-natural experiment, Review of Finance 19, 95-144.

Ivashina, Victoria, 2009, Asymmetric information effects on loan spreads, Journal of Financial Economics 92, 300-319. 
Ivashina, Victoria, and David Scharfstein, 2010, Bank lending during the financial crisis of 2008, Journal of Financial Economics 97(3), 319-338.

Jiménez, Gabriel, Steven Ongena, José L. Peydró, and Jesús Saurina, 2014, Hazardous Times for Monetary Policy: What do 23 Million Loans Say About the Impact of Monetary Policy on Credit Risk-Taking?, Econometrica 82(2), 463-505.

Jiménez, Gabriel, Steven Ongena, José L. Peydró, and Jesús Saurina, 2012, Credit supply and monetary policy: Identifying the bank balance-sheet channel with loan applications, American Economic Review 102.

Kashyap Anil K., and Jeremy C. Stein, 1994, Monetary policy and bank lending, in N. Gregory Mankiw, ed.: Monetary policy (University of Chicago Press).

Kashyap Anil K., and Jeremy C. Stein, 1995. The impact of monetary policy on bank balance sheets. Carnegie-Rochester Conference Series on Public Policy 42, pp. 151-195.

Kashyap, Anil K., and Jeremy C. Stein, 2000, What do a million observations on banks say about the transmission of monetary policy?, The American Economic Review 90, 407-428.

Kashyap Anil K., Owen Lamont, and Jeremy C. Stein, 1994, Credit conditions and the cyclical behavior of inventories, Quarterly Journal of Economics 109, 565-592.

Kocherlakota, Narayana R., 1990, On tests of representative consumer asset pricing models, Journal of Monetary Economics 26(2), 285-304.

Kishan, Ruby P., Timothy P. Opiela, 2000. Bank size, bank capital, and the bank lending channel. Journal of Money, Credit and Banking 32, 121-141.

Lawrence J. Christiano, Martin Eichenbaum, and Charles L. Evans, 2005, Nominal rigidities and the dynamic effects of a shock to monetary policy, Journal of Political Economy 113, 145 . 
Oster, Emily, 2019. Unobservable selection and coefficient stability: theory and evidence. Journal of Business \& Economic Statistics 37, 187-204.

Peek, Joe, and Eric S. Rosengren, 1995, Bank lending and the transmission of monetary policy, FRB Boston Conference Series, 47-68.

Peek, Joe, and Eric S. Rosengren, 2015, The role of banks in the transmission of monetary policy, in Berger, Allen N., P. Molyneux, and John O.S. Wilson, ed.: The Oxford Handbook of Banking (1ed), pp. 453-473.

Popov, Alexander, and Neeltje van Horen, 2015, Exporting sovereign stress: Evidence from syndicated bank lending during the euro area sovereign debt crisis, Review of Finance 19(5), $1825-1866$.

Röller, Lars-Hendrik, and Leonard Waverman, 2001, Telecommunications Infrastructure and Economic Development: A Simultaneous Approach, American Economic Review 91(4), 909923.

Tauchen, George, 1986, Statistical properties of generalized method-of-moments estimators of structural parameters obtained from financial market data, Journal of Business and Economic Statistics 4(4), 397-416.

Thompson, S., 2011, Simple formulas for standard errors that cluster by both firm and time, Journal of Financial Economics, 99, 1:1-10. 
Figure 1. Central bank liquidity

Figure 1 shows the weekly aggregate market liquidity provided to the banking sector by the ECB (Central Bank Liquidity) during the January 2006 to June 2010 period. It is calculated in Panel A as the sum of banks' current account and deposit facility holdings with the ECB, centered around its mean value in 2006. In Panel B, Excess Liquidity is calculated as the sum of banks' current account and deposit facility holdings with the ECB divided by the minimum reserve requirement imposed by the ECB for the specific reserve maintenance period, minus 1 . The vertical dashed lines indicate (1) the start of the financial crisis in August 2007; (2) the start of the full allotment period in October 2008; and (3) the first longer-term refinancing operation (LTRO) with a maturity of one year as a fixed rate tender procedure with full allotment in June 2009. All variables are defined in Appendix A1.

\section{Panel A. Central bank liquidity}

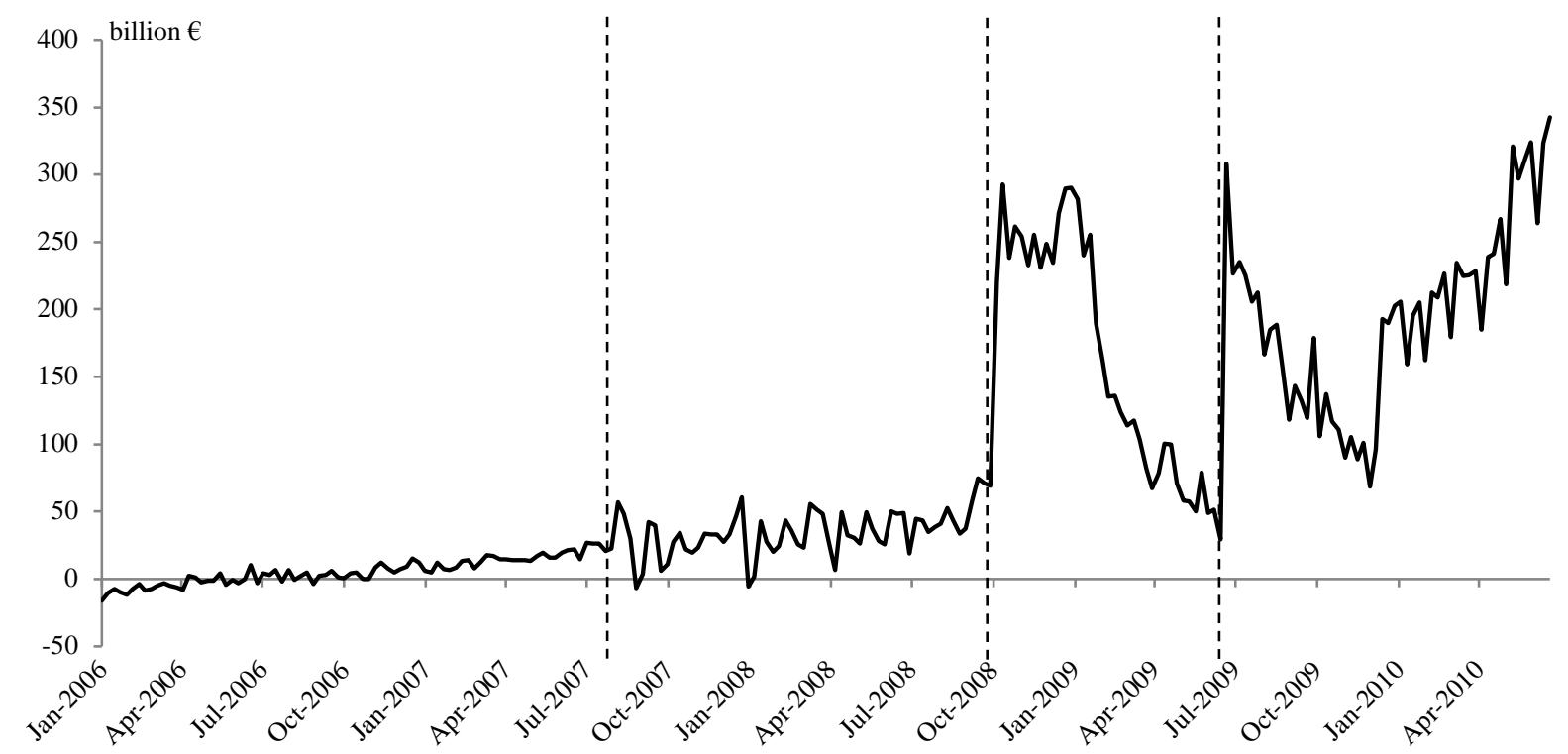

\section{Panel B. Excess liquidity}

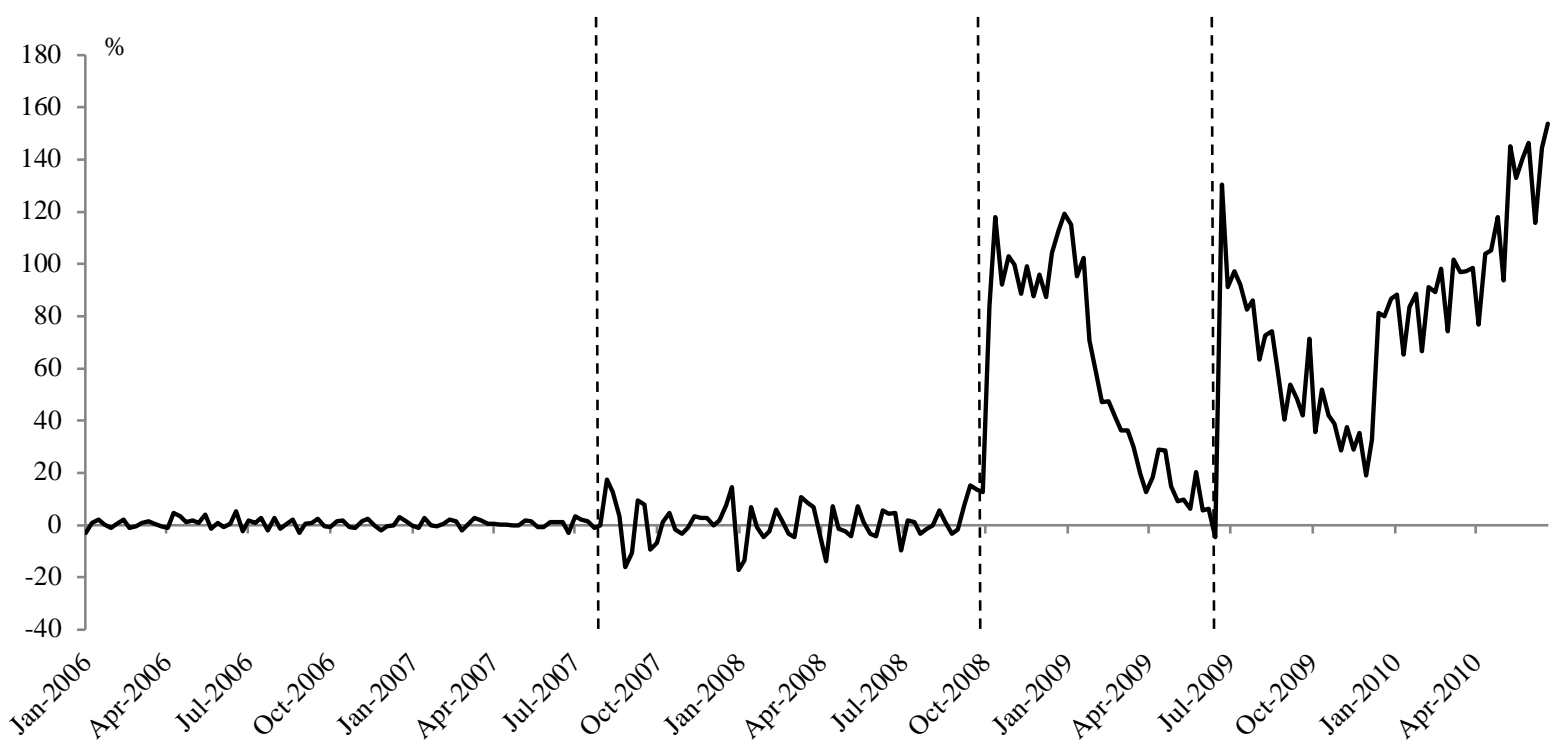


Figure 2. Short-term interest rates and central bank liquidity

Panel A of Figure 2 shows the development of the interest rates for the ECB Deposit Facility, the ECB Main Refinancing Operations, and the ECB Marginal Lending Facility aggregated to the weekly level, together with the average weekly Corporate Short-Term Deposit Rate in percent over the January 2006 to June 2010 period. Panel B illustrates the development of the Deposit Spread (solid line, in bps, axis on the left) and the Adjusted Liquidity in the Banking Sector (dashed line, $€$ billion, axis on the right), both aggregated to the weekly level. The vertical dashed lines indicate (1) the start of the financial crisis in August 2007; (2) the start of the full allotment period in October 2008; and (3) the first longer-term refinancing operation (LTRO) with a maturity of one year as a fixed rate tender procedure with full allotment in June 2009. All variables are defined in Appendix A1.

\section{Panel A: Short-term interest rates}

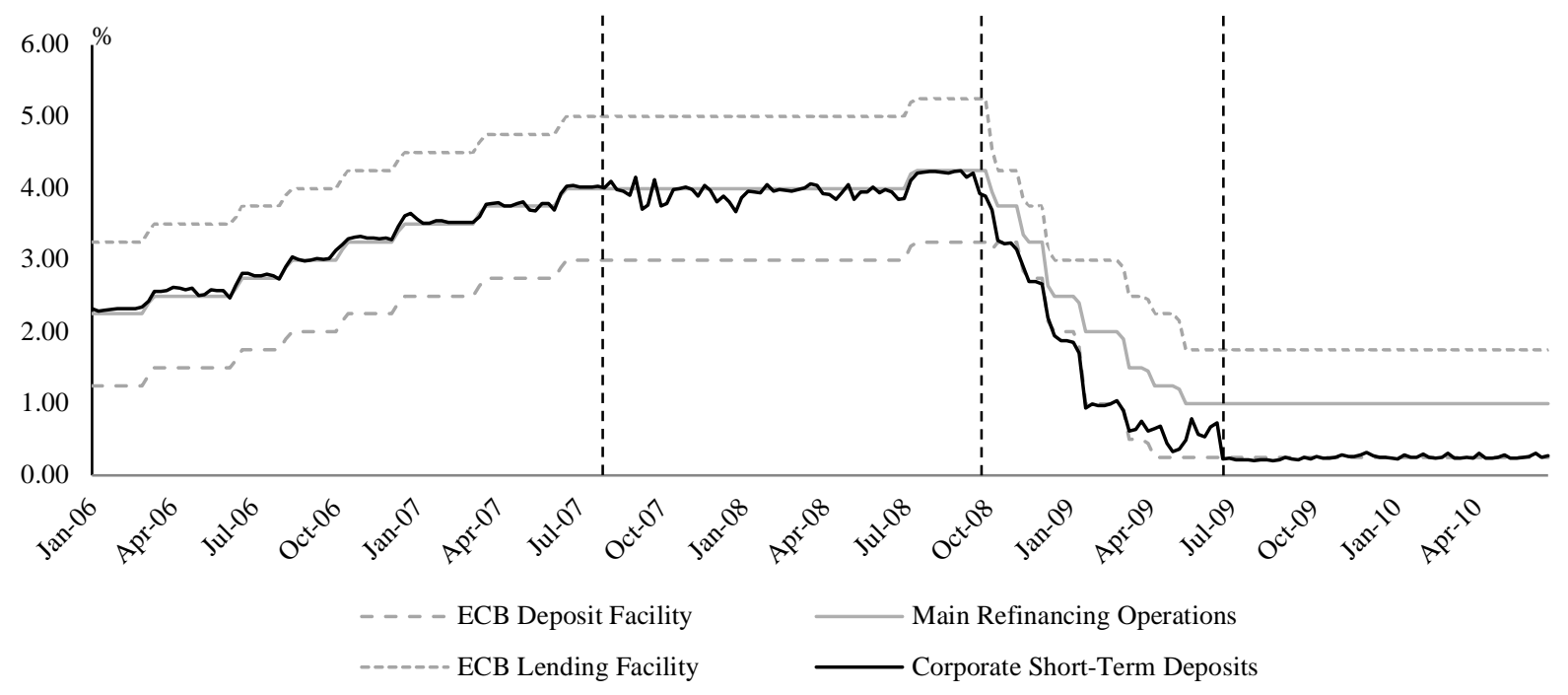

\section{Panel B: Central bank liquidity and deposit spread}

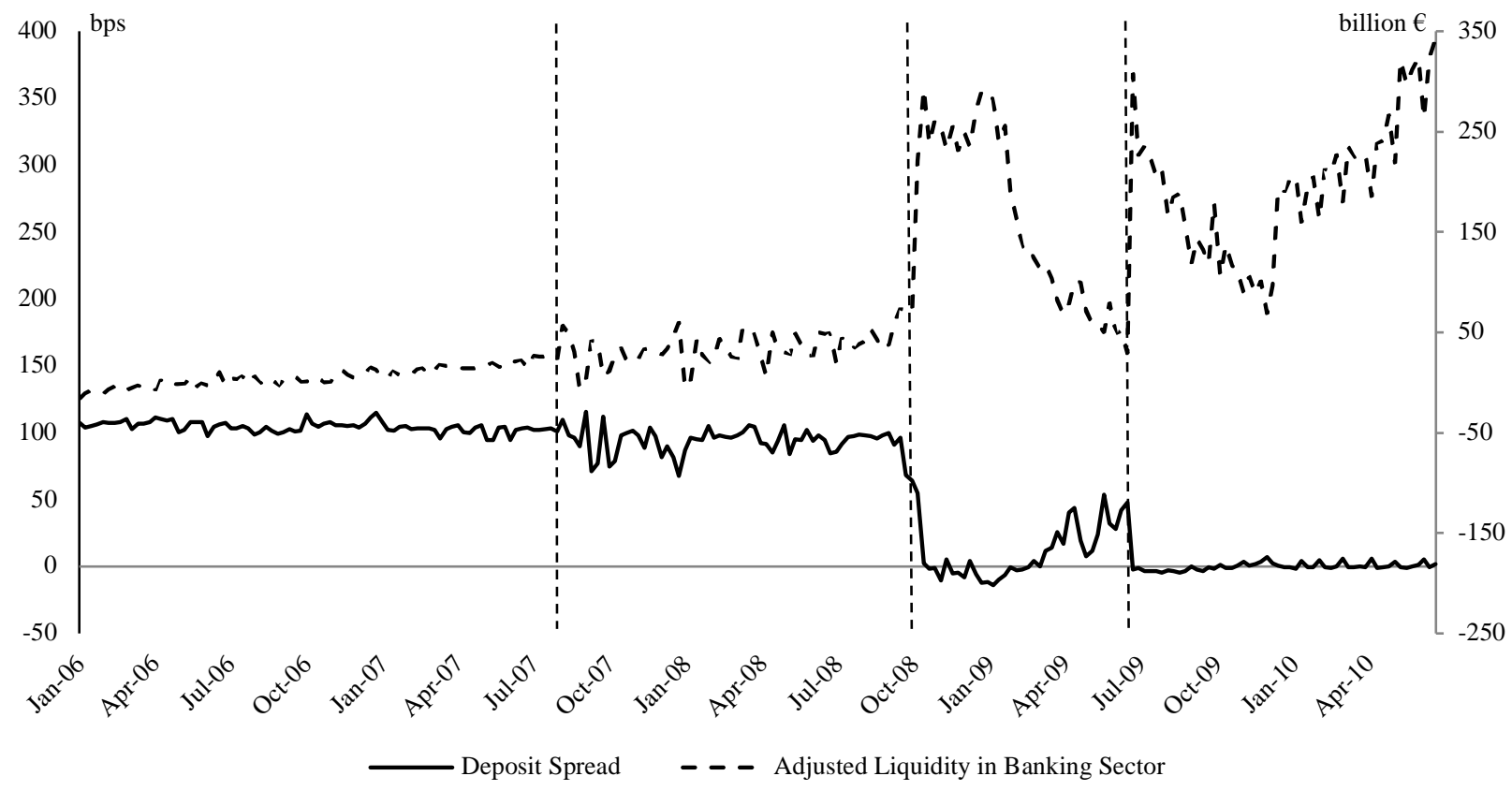


Figure 3. Bank risk and deposit and loan spreads

Figure 3 shows banks' average five-year CDS Spread by bank risk category (Panel A), the Deposit Spread by bank risk category (Panel B), and the Loan Spread difference of borrowers on the intensive margin by bank risk category (Panel C) in basis points from January 2006 to June 2010. The vertical dashed lines indicate (1) the start of the financial crisis in August 2007; (2) the start of the full allotment period in October 2008; and (3) the first longer-term refinancing operation (LTRO) with a maturity of one year as a fixed rate tender procedure with full allotment in June 2009. All variables are defined in Appendix A1 and Online Appendix A.

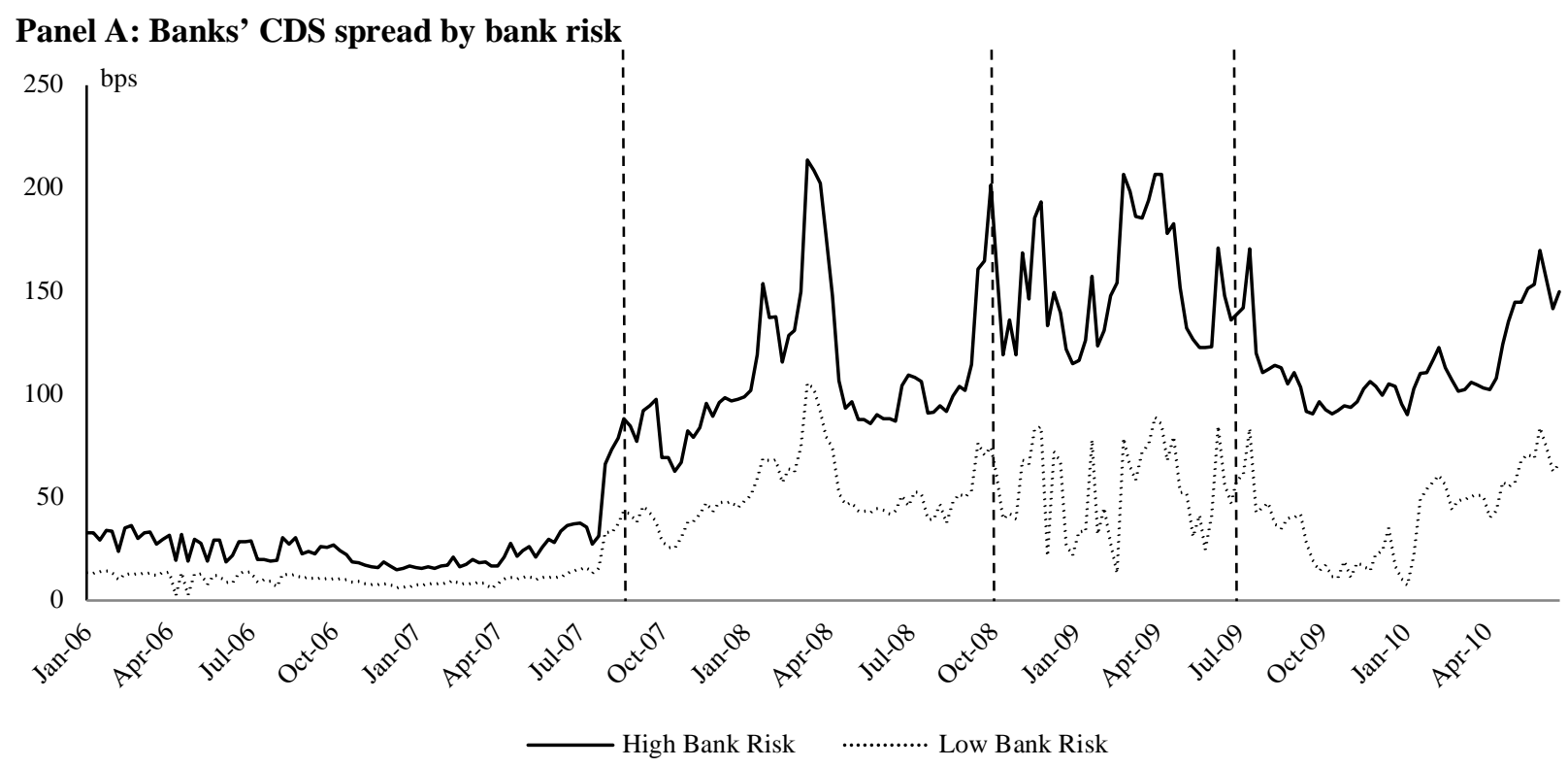

Panel B: Deposit spread by bank risk

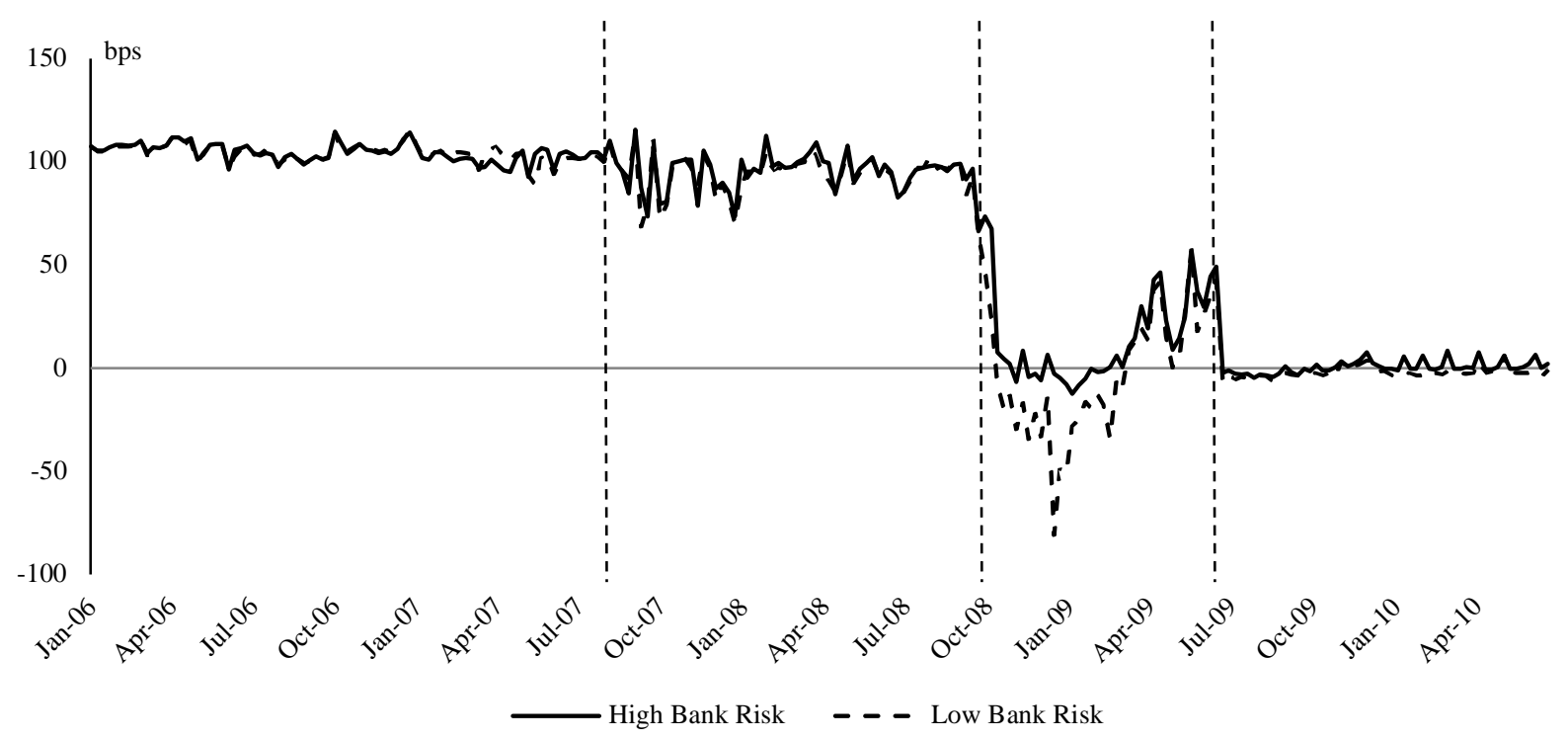


Panel C: Loan spread difference between low- and high-risk bank borrowers (intensive margin)

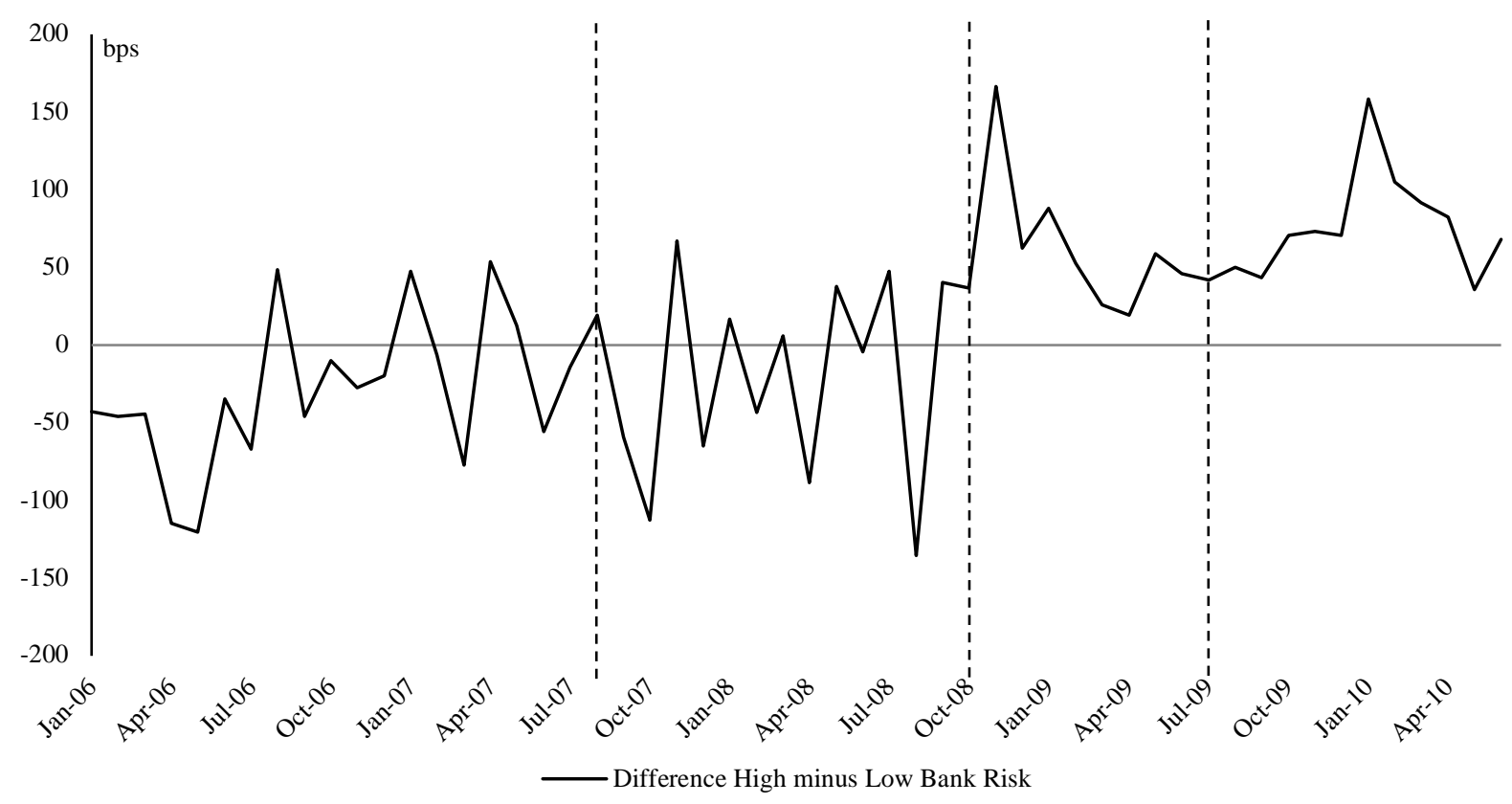




\section{Table 1. Descriptive statistics}

This table shows the descriptive statistics of variables for the January 2006 to June 2010 period. This period is also split into the financial crisis until the full allotment period from August 9, 2007 to October 7, 2008, and the full allotment period from October 8, 2008 until June 30, 2010. All variables are defined in Appendix A1. Further descriptive statistics are shown in Online Appendix B. The Adjusted Liquidity in the Banking Sector is shown without taking the logarithm before centering it. The Deposit Rate is reported in basis points (bps) per annum using an actual/360-day count convention. The Deposit Spread is calculated as the difference between the deposit rate and the ECB deposit facility rate.

\begin{tabular}{|c|c|c|c|c|c|c|c|c|c|}
\hline & \multicolumn{3}{|c|}{$\begin{array}{c}\text { Total Period } \\
(2006: \mathrm{Q} 1-2010: \mathrm{Q} 2) \\
43 \text { banks; 40,638 deposits; 2,632 loans }\end{array}$} & \multicolumn{3}{|c|}{$\begin{array}{l}\text { Crisis until Full Allotment } \\
\text { (Aug. 9, 2007-Oct. 7, 2008) } \\
35 \text { banks; 12,078 deposits; } 725 \text { loans }\end{array}$} & \multicolumn{3}{|c|}{$\begin{array}{c}\text { Full Allotment Period } \\
\text { (Oct. 8, 2008-2010:Q2) } \\
40 \text { banks; 20,104 deposits; } 775 \text { loans }\end{array}$} \\
\hline & Mean & St.Dev. & Median & Mean & St.Dev. & Median & Mean & St.Dev. & Median \\
\hline \multicolumn{10}{|l|}{ CENTRAL BANK LIQUIDITY } \\
\hline Adjusted Central Bank Liquidity ( $€$ bn) & 81.80 & 98.98 & 34.84 & 35.21 & 28.50 & 33.70 & 183.14 & 88.14 & 201.23 \\
\hline \multicolumn{10}{|l|}{ CORPORATE DEPOSITS } \\
\hline Deposit Rate (bps) & 226.70 & 162.88 & 274.00 & 398.46 & 21.00 & 399.00 & 81.15 & 94.19 & 29.00 \\
\hline Deposit Spread (bps) & 51.41 & 50.36 & 58.00 & 93.29 & 19.16 & 98.00 & 4.16 & 20.80 & 0.00 \\
\hline $\log$ (Notional Deposit Amount) & 17.15 & 1.62 & 17.37 & 17.20 & 1.71 & 17.50 & 17.14 & 1.50 & 17.19 \\
\hline Average Duration (days) & 1.86 & 1.55 & 1.00 & 1.83 & 1.53 & 1.00 & 1.89 & 1.56 & 1.00 \\
\hline Bank Competition & 0.10 & 0.02 & 0.10 & 0.10 & 0.02 & 0.10 & 0.10 & 0.02 & 0.09 \\
\hline \multicolumn{10}{|l|}{ LOAN CHARACTERISTICS } \\
\hline All in Spread Drawn (bps) & 183.45 & 145.66 & 175.00 & 160.40 & 128.66 & 125.00 & 306.52 & 148.86 & 300.00 \\
\hline Log(Maturity in Months) & 3.83 & 0.64 & 4.09 & 3.71 & 0.72 & 4.09 & 3.64 & 0.55 & 3.58 \\
\hline $\log ($ Facility Size $)$ & 19.76 & 1.28 & 19.81 & 20.01 & 1.36 & 20.18 & 19.74 & 1.08 & 19.78 \\
\hline $\log ($ Number of Previous Loans of Borrower) & 1.53 & 0.91 & 1.61 & 1.41 & 0.94 & 1.61 & 1.76 & 0.87 & 1.95 \\
\hline \multicolumn{10}{|l|}{ BANK CHARACTERISTICS } \\
\hline Low Bank Risk CDS spread & 49.59 & 34.40 & 50.00 & 61.95 & 30.40 & 58.00 & 71.32 & 27.46 & 68.00 \\
\hline High Bank Risk CDS spread & 109.87 & 64.38 & 104.00 & 110.20 & 44.80 & 120.00 & 126.85 & 60.69 & 124.00 \\
\hline Total Assets (€ million) & 13.28 & 0.74 & 13.29 & 13.33 & 0.70 & 13.31 & 13.30 & 0.80 & 13.29 \\
\hline
\end{tabular}




\section{Table 2. Transmission of monetary policy to deposits}

Table 2 reports OLS regression results of Deposit Spread on Aggregate Central Bank Liquidity, bank risk, and other control variables using transaction data aggregated to the bank-firm-week level over different time periods. The regressions include Log(Notional Deposit Amount) as the logarithm of the total deposited amount of a firm with a bank over a week and Central Bank Liquidity as the average over this week. Further control variables are used with their average values using all transactions of a firm with a bank over a week. Bank accounting variables are used as stated in the annual report in the year prior to the transaction. The full specification is shown in an Online Appendix. Central Bank Liquidity is measured as the adjusted liquidity in the banking sector. High Bank Risk is a dummy variable defined using banks' CDS spreads and explained in detail in Online Appendix A. All variables are defined in Appendix A1. The statistical significance of results is indicated by $*=10 \%$ level, $* *=5 \%$ level and $* * *=1 \%$ level using two-way clustered standard errors at the bank and at the week level using the method as proposed by Cameron, Gelbach, and Miller (2011) and Thompson (2011).

\begin{tabular}{lcccc}
\hline & Total Period & $\begin{array}{c}\text { Pre-Financial } \\
\text { Crisis }\end{array}$ & $\begin{array}{c}\text { Crisis Until Full } \\
\text { Allotment } \\
(3)\end{array}$ & $\begin{array}{c}\text { Full Allotment } \\
\text { Period } \\
(4)\end{array}$ \\
\hline ECB Market Liquidity & $(1)$ & $(2)$ & & \\
Central Bank Liquidity & & & & $-25.972^{* * *}$ \\
High Bank Risk & $-27.052^{* * *}$ & 4.426 & 1.193 & $-27.474^{* * *}$ \\
Log(Notional Deposit Amount) & 0.621 & 0.193 & $-0.410^{* *}$ & $-1.638^{* * * *}$ \\
Crisis Until Full Allotment & $-0.773^{* *}$ & $-1.050^{*}$ & & \\
Full Allotment Period & 1.534 & & & \\
Control Variables & $-90.406^{* * *}$ & & Yes & Yes \\
Firm FE & Yes & Yes & Yes & Yes \\
Time (month) FE & Yes & Yes & Yes & Yes \\
\hline Observations & Yes & Yes & 3,866 & 5,560 \\
R-squared & 11,533 & 2,045 & 0.341 & 0.604 \\
\hline
\end{tabular}




\section{Table 3. Transmission of monetary policy to deposits for high- versus low-risk banks}

This table reports the OLS regression results of the Deposit Spread of corporate deposits on Central Bank Liquidity, bank risk and further control variables aggregated to the bank-firm-week level. The regressions include Log(Notional Deposit Amount) as the logarithm of the total deposited amount of a firm with a bank over a week. The table shows the results of different regression specifications using data from the crisis until the full allotment period in Panel A and from the full allotment period in Panel B. Central Bank Liquidity is measured as the adjusted liquidity in the banking sector. High Bank Risk is a dummy variable defined using banks' CDS spreads and explained in detail in Online Appendix A. All variables are defined in Appendix A1. All specifications include the same control variables as in Table 2. The statistical significance of results is indicated by $*=10 \%$ level, $* *=5 \%$ level and $* * *=1 \%$ level using two-way clustered standard errors at the bank and at the week level using the method as proposed by Cameron, Gelbach and Miller (2011) and Thompson (2011).

Panel A. Crisis until full allotment period

\begin{tabular}{cccc} 
No Control & Bank Risk $\times$ Time & \multirow{2}{*}{ Bank $\times$ Time FE } & Firm $\times$ Time and \\
Variables & FE & & Firm $\times$ Bank FE
\end{tabular}

(1)

(2)

(3)

(4)

\begin{tabular}{lcccc}
\hline ECB Market Liquidity & & & \\
Central Bank Liquidity $\times$ High Bank Risk & -18.837 & -7.804 & -9.219 & -6.425 \\
Central Bank Liquidity $\times$ Low Bank Risk & $-25.041^{* *}$ & $-30.979^{* * *}$ & $-31.129^{* * *}$ & $-32.151^{* * *}$ \\
Log Notional Deposit Amount) & & $-0.499^{*}$ & $-0.208^{*}$ & $-0.201^{* *}$ \\
Control Variables & No & Yes & Yes & Yes \\
Bank Risk $\times$ Time (month) FE & No & Yes & No & No \\
Bank $\times$ Time (month) FE & No & No & Yes & Yes \\
Firm FE & No & Yes & Yes & No \\
Firm $\times$ Time (month) FE & No & No & No & Yes \\
Firm $\times$ Bank FE & No & No & No & Yes \\
\hline Wald Test of Interaction Terms & 0.0547 & 0.0021 & 0.0046 & 0.0022 \\
Observations & 4,079 & 3,866 & 3,866 & 3,692 \\
R-squared & 0.037 & 0.355 & 0.441 & 0.550 \\
\hline
\end{tabular}

Panel B. Full allotment period

$\begin{array}{cccc}\text { No Control } & \text { Bank Risk } \times \text { Time } & \text { Bank } \times \text { Time FE } & \text { Firm } \times \text { Time and } \\ \text { Variables } & \text { FE } & & \text { Firm } \times \text { Bank FE }\end{array}$

(1) (2) (3) (4)

\begin{tabular}{|c|c|c|c|c|}
\hline \multicolumn{5}{|l|}{ ECB Market Liquidity } \\
\hline Central Bank Liquidity $\times$ High Bank Risk & $-31.497 * * *$ & $-27.721 * * *$ & $-27.000 * * *$ & $-26.792 * * *$ \\
\hline Central Bank Liquidity $\times$ Low Bank Risk & $-39.347 * * *$ & $-25.773 * * *$ & $-28.483 * * *$ & $-31.483^{* * *}$ \\
\hline Log(Notional Deposit Amount) & & $-1.628 * *$ & $-0.798 * *$ & $-0.722 * * *$ \\
\hline Control Variables & No & Yes & Yes & Yes \\
\hline Bank Risk $\times$ Time (month) FE & No & Yes & No & No \\
\hline Bank $\times$ Time (month) FE & No & No & Yes & Yes \\
\hline Firm FE & No & Yes & Yes & No \\
\hline Firm $\times$ Time (month) FE & No & No & No & Yes \\
\hline Firm $\times$ Bank FE & No & No & No & Yes \\
\hline Wald Test of Interaction Terms & 0.1846 & 0.6242 & 0.6063 & 0.2257 \\
\hline Observations & 6,239 & 5,560 & 5,560 & 5,297 \\
\hline R-squared & 0.224 & 0.614 & 0.784 & 0.833 \\
\hline
\end{tabular}




\section{Table 4. Tracing out corporate deposit demand}

This table reports results to address possible endogeneity concerns associated with the transmission of ECB liquidity to deposit spreads during the full allotment period. It shows the results of an estimation of a system of equations using GMM including aggregate data at the bank-firm-week level. End of Maintenance Period is a dummy variable which is 1 in the last week of a reserve maintenance period. Excess Cash is a continuous measure of firms' aggregate quarterly excess cash holdings. Central Bank Liquidity is measured as the adjusted liquidity in the banking sector. High Bank Risk is a dummy variable defined using banks' CDS spreads and explained in detail in Online Appendix A. All variables are defined in Appendix A1. System identification is tested following Baum, Schaffer, and Stillman (2007). The statistical significance of results is indicated by $*=10 \%$ level, $* *=5 \%$ level and $* * *=1 \%$ level using standard errors clustered at the bank-week level.

\begin{tabular}{|c|c|c|c|}
\hline & $\begin{array}{c}\text { Central Bank } \\
\text { Liquidity } \\
\text { (1) }\end{array}$ & $\begin{array}{c}\text { Deposit Supply } \\
\text { Log(Notional } \\
\text { Deposit Amount) } \\
\text { (2) }\end{array}$ & $\begin{array}{c}\text { Deposit Demand } \\
\text { Deposit Spread } \\
\text { (3) }\end{array}$ \\
\hline End of Maintenance Period & $-0.836^{* * *}$ & & \\
\hline Excess Cash & & $0.086 * * *$ & \\
\hline \multicolumn{4}{|l|}{ ECB Market Liquidity } \\
\hline Central Bank Liquidity $\times$ High Bank Risk & & $0.140^{* *}$ & $-26.201 * *$ \\
\hline Central Bank Liquidity $\times$ Low Bank Risk & & $0.169 * * *$ & $-29.920 * * *$ \\
\hline High Bank Risk & & -0.089 & -2.290 \\
\hline Deposit Spread & & $0.019 * * *$ & \\
\hline $\log$ (Notional Deposit Amount) & & & $-0.655^{* * *}$ \\
\hline Interbank Deposits & $-3.277 * * *$ & & \\
\hline Retail Deposits & $12.961 * * *$ & & \\
\hline Corporate Deposits & $0.150 * * *$ & & \\
\hline Control Variables & Yes & Yes & Yes \\
\hline Bank $\times$ Time (year) FE & Yes & Yes & Yes \\
\hline Firm $\times$ Time (year) FE & Yes & Yes & Yes \\
\hline Bank $\times$ Firm FE & Yes & Yes & Yes \\
\hline Wald Test of Interaction Terms & & & 0.353 \\
\hline Observations & 5,297 & 5,297 & 5,297 \\
\hline R-squared & 0.916 & 0.423 & 0.842 \\
\hline System identification & Yes & Yes & Yes \\
\hline J-statistic p-val. & 0.883 & & \\
\hline
\end{tabular}


Table 5. The transmission of central bank liquidity to loan spreads

This table reports OLS regression results of syndicated loan spreads on Central Bank Liquidity, bank risk, and additional control variables. It shows six different regression specifications over different time periods. Central Bank Liquidity is measured as the average over the quarter prior to loan origination of the adjusted liquidity in the banking sector. High Bank Risk is a dummy variable defined using banks' CDS spreads and explained in detail in Online Appendix A. All variables are defined in Appendix A1. Bank and borrower accounting variables are used as stated in the annual report in the year prior to the transaction. The full specification in Panel B is shown in Online Appendix F. Standard errors are clustered at the firm and at the week level using the method as proposed by Cameron, Gelbach and Miller (2011) and Thompson (2011). The statistical significance of results is indicated by $*=10 \%$ level, $* *=5 \%$ level and $* * *=1 \%$ level.

$\underline{\text { Panel A. Baseline regression without control variables }}$

\begin{tabular}{|c|c|c|c|c|c|c|}
\hline & \multicolumn{2}{|c|}{ Financial Crisis Period } & \multicolumn{2}{|c|}{ Crisis Until Full Allotment } & \multicolumn{2}{|c|}{ Full Allotment Period } \\
\hline & (1) & (2) & (3) & (4) & (5) & (6) \\
\hline Central Bank Liquidity & $-47.779 * * *$ & & 87.831 & & $-155.224 *$ & \\
\hline Central Bank Liquidity $\times$ High Bank Risk & & -21.138 & & 97.574 & & -83.411 \\
\hline Central Bank Liquidity $\times$ Low Bank Risk & & $-87.297 *$ & & 67.598 & & $-184.770 * *$ \\
\hline \multicolumn{7}{|l|}{ Bank Risk } \\
\hline High Bank Risk & 26.405 & 26.251 & 7.914 & 76.079 & 23.735 & -27.915 \\
\hline Borrower Characteristics & No & No & No & No & No & No \\
\hline Bank Characteristics & No & No & No & No & No & No \\
\hline Further Control Variables & No & No & No & No & No & No \\
\hline Wald Test of Interaction Terms & & 0.0837 & & 0.541 & & 0.0396 \\
\hline Observations & 1,156 & 1,156 & 533 & 533 & 623 & 623 \\
\hline R-squared & 0.160 & 0.161 & 0.053 & 0.054 & 0.029 & 0.037 \\
\hline
\end{tabular}

Panel B. With control variables

\begin{tabular}{|c|c|c|c|c|c|c|}
\hline & \multicolumn{2}{|c|}{ Financial Crisis Period } & \multicolumn{2}{|c|}{ Crisis Until Full Allotment } & \multicolumn{2}{|c|}{ Full Allotment Period } \\
\hline & (1) & (2) & (3) & (4) & $(5)$ & (6) \\
\hline Central Bank Liquidity & $-102.007 * *$ & & -67.633 & & -82.160 & \\
\hline Central Bank Liquidity $\times$ High Bank Risk & & -76.103 & & -63.068 & & -49.064 \\
\hline Central Bank Liquidity $\times$ Low Bank Risk & & $-150.996 * * *$ & & -75.281 & & $-164.009 * * *$ \\
\hline \multicolumn{7}{|l|}{ Bank Risk } \\
\hline High Bank Risk & 26.321 & $46.224 * * *$ & $38.035 * * *$ & 67.459 & 12.649 & -21.910 \\
\hline Borrower Characteristics & Yes & Yes & Yes & Yes & Yes & Yes \\
\hline Bank Characteristics & Yes & Yes & Yes & Yes & Yes & Yes \\
\hline Loan Characteristics & Yes & Yes & Yes & Yes & Yes & Yes \\
\hline Macro Environment & Yes & Yes & Yes & Yes & Yes & Yes \\
\hline Bank Risk $\times$ Time (year) FE & Yes & Yes & Yes & Yes & Yes & Yes \\
\hline Borrower Rating FE & Yes & Yes & Yes & Yes & Yes & Yes \\
\hline Borrower Industry Code FE & Yes & Yes & Yes & Yes & Yes & Yes \\
\hline Loan Type, Purpose, Currency FE & Yes & Yes & Yes & Yes & Yes & Yes \\
\hline Wald Test of Interaction Terms & & 0.0115 & & 0.2557 & & 0.0123 \\
\hline Observations & 1,156 & 1,156 & 533 & 533 & 623 & 623 \\
\hline R-squared & 0.755 & 0.756 & 0.824 & 0.824 & 0.733 & 0.735 \\
\hline
\end{tabular}




\section{Table 6. Intensive and Extensive Margin}

Panel A reports regression results where the dependent variable is an indicator variable that is 1 if a borrower has received a loan from the same bank risk category prior and during the full allotment period (intensive margin). All variables are defined in Appendix A1 and Online Appendix A. The borrower variables are Log(total assets), leverage, current ratio, coverage, market-to-book, and tangibility. The control variables are $\log (\operatorname{maturity}$ in months), secured, $\log$ (facility size), $\log$ (number of loans of borrower), performance pricing, the three-month EURIBOR-EONIA swap spread, quarterly EU GDP growth (\%), the CISS, and the main refinancing rate. Standard errors are heteroscedasticityrobust and clustered at the firm level. Panel B reports OLS regression results of AISD on Central Bank Liquidity, bank risk, and control variables focusing on borrowing along the intensive margin (Column (1)). Column (2) shows the second stage of a Heckman regression model using Column (3) of Panel A as the first stage. The statistical significance of results is indicated by $*=10 \%$ level, $* *=5 \%$ level and $* * *=1 \%$ level. In Column (1), standard errors are clustered at the firm level. In Column (2), standard errors are derived using resampling via the jackknife method and clustered at the firm level.

Panel A. Probability to observe a loan of an existing borrower of bank risk category (intensive margin)

\begin{tabular}{lcccc}
\hline & $(1)$ & $(2)$ & $(3)$ & $(4)$ \\
Estimation Method & OLS & Logit & Probit & OLS \\
\hline Bank Risk & & & & \\
High Bank Risk & -0.124 & -0.632 & -0.294 & 0.092 \\
Bank Accounting Variables & & & -0.367 \\
Log(Total Assets) & -0.014 & -0.107 & -0.051 & -0.027 \\
Leverage & 0.012 & 0.045 & 0.038 & 0.006 \\
Return on Assets & 0.015 & 0.096 & 0.071 & 0.002 \\
Total Asset Growth & 0.001 & 0.002 & 0.001 & 0.034 \\
Non-performing Loans/Total Loans & -0.035 & -0.112 & -0.075 & Yes \\
Borrower Characteristics & Yes & Yes & Yes & Yes \\
Further Control Variables & Yes & Yes & Yes & Yes \\
Bank Risk $\times$ Time FE (year) & No & No & No & Yes \\
Borrower Rating FE & No & No & No & Yes \\
Borrower Industry Code FE & No & No & No & Yes \\
Loan Type, Purpose, Currency FE & No & No & 754 & 623 \\
\hline Observations & 754 & 754 & No & Yes \\
Clustering (Firm) & No & No & 0.178 & 0.554 \\
R-squared / Pseudo R-squared & 0.215 & 0.175 & & \\
\hline
\end{tabular}

Panel B. Heckman selection model

\begin{tabular}{|c|c|c|}
\hline & $\begin{array}{l}(1) \\
\text { OLS }\end{array}$ & $\begin{array}{c}(2) \\
\text { Heckman Model }\end{array}$ \\
\hline Central Bank Liquidity $\times$ High Bank Risk & -154.405 & -197.942 \\
\hline Central Bank Liquidity $\times$ Low Bank Risk & $-258.384 * *$ & $-315.840 * *$ \\
\hline Bank Risk $\times$ Time FE (year) & Yes & Yes \\
\hline Borrower Rating FE & Yes & Yes \\
\hline Borrower Industry Code FE & Yes & Yes \\
\hline Loan Type, Purpose, Currency FE & Yes & Yes \\
\hline Observations (for (2): Uncensored / Censored / Total) & 272 & $272 / 422 / 694$ \\
\hline Observations_-Borrow Only From High Bank Risk Prior to Full Allotment & 58 & 58 \\
\hline Observations_-Borrow Only From Low Bank Risk Prior to Full Allotment & 13 & 13 \\
\hline Observations-Borrow From Both Bank Risk Categories Prior to Full Allotment & 201 & 201 \\
\hline Wald Test of Interaction Terms & 0.0252 & 0.0247 \\
\hline R-squared & 0.776 & \\
\hline
\end{tabular}


Table 7. Central bank liquidity and loan spreads: Robustness

This table reports regression results of borrowers along the intensive margin in the full allotment period. Panel A shows results from propensity score matching using a nearest neighbor estimator with 10, 50, and 100 nearest neighbors all with a caliper of 0.1 together with a Gaussian and an Epanechnikov kernel estimator, both with a bandwidth of 0.01 . The propensity score is estimated using a logit regression model and borrowers are matched on the odds ratio. Standard errors are reported in parentheses using 50 bootstrap replications. Panel B reports OLS regressions of the AISD of matched borrowers on Central Bank Liquidity interacted with High Bank Risk or Low Bank Risk. Columns (1) and (2) show the results using the nearest neighbor matching $(n=1)$. Columns (3) and (4) report the results using kernel matching within a bandwidth of 0.1 . The regressions include the same bank control variables as in Panel B of Table 5 . Panel $\mathrm{C}$ uses the specification from Panel B of Table 5 during the full allotment period and additionally includes interactions between Central Bank Liquidity, bank risk category, and borrower characteristics which might especially be related to monetary policy. As shown in Online Appendix G, these are borrower Total Assets, Leverage, and Current Ratio. All variables are explained in Appendix A1. Standard errors are clustered at the firm and at the week level using the method as proposed by Cameron, Gelbach and Miller (2011) and Thompson (2011). The statistical significance of results is indicated by $*=10 \%$ level, $* *=5 \%$ level and $* * *=1 \%$ level.

Panel A: Propensity score matching

\begin{tabular}{llc}
\hline & Estimation Method & Intensive Margin \\
\hline High Bank Risk & Nearest Neighbor $(n=10)$ & $121.385^{* * *}$ \\
High Bank Risk & Nearest Neighbor $(n=50)$ & $121.277^{* * *}$ \\
High Bank Risk & Nearest Neighbor $(n=100)$ & $121.277^{* * *}$ \\
High Bank Risk & Gaussian Kernel & $99.725^{* *}$ \\
High Bank Risk & Epanechnikov Kernel & $99.725^{* * *}$ \\
\hline
\end{tabular}

Panel B: Loan spread-intensive margin-matched borrowers

\begin{tabular}{lcccc}
\hline & $(1)$ & $(2)$ & $(3)$ & $(4)$ \\
Matching Method & Nearest Neighbor Matching & \multicolumn{2}{c}{ Kernel Matching } \\
\hline Central Bank Liquidity $\times$ High Bank Risk & $-39.895^{*}$ & 40.897 & -166.558 & -133.954 \\
Central Bank Liquidity $\times$ Low Bank Risk & $-121.089^{* * *}$ & $-155.680^{* *}$ & $-212.002^{* *}$ & $-214.211^{* *}$ \\
High Bank Risk & -10.182 & -70.065 & -16.043 & -78.054 \\
Bank Control Variables & No & Yes & No & Yes \\
\hline Observations & 264 & 264 & 358 & 358 \\
Wald Test of Interaction Terms & 0.0175 & 0.0489 & 0.0982 & 0.0527 \\
R-squared & 0.0995 & 0.1644 & 0.1005 & 0.1483 \\
\hline
\end{tabular}

Panel C: Central bank liquidity interacted with borrower characteristics

\begin{tabular}{lcc}
\hline Variable & $\begin{array}{c}\text { Total Assets, } \\
\text { Leverage, } \\
\text { Current Ratio } \\
(1)\end{array}$ & $\begin{array}{c}\text { Borrower Rating } \\
(2)\end{array}$ \\
\hline Central Bank Liquidity & & 46.672 \\
(1) Central Bank Liquidity $\times$ High Bank Risk & 60.226 & $-164.815^{* * *}$ \\
(2) Central Bank Liquidity $\times$ Low Bank Risk & $-291.027^{* *}$ & Yes \\
Central Bank Liquidity $\times$ High Bank Risk $\times$ Variable & Yes & Yes \\
Central Bank Liquidity $\times$ Low Bank Risk $\times$ Variable & Yes & Yes \\
Further Controls & Yes & Yes \\
Bank Risk $\times$ Time FE (year) & Yes & Yes \\
Borrower Rating FE & Yes & Yes \\
Borrower Industry Code FE & Yes & Yes \\
Loan Type, Purpose, Currency FE & Yes & Yes \\
Clustering (Firm) & Yes & 0.0184 \\
\hline Wald Test of Interaction Terms (1) $=(2)$ & 0.0016 & 623 \\
Observations & 623 & 0.736 \\
R-squared & 0.744 & \\
\hline
\end{tabular}




\section{Table 8. Monetary policy, loan maturity, and bank-dependence}

This table reports regression results of AISD on Central Bank Liquidity, bank risk, and additional control variables in the full allotment period. In Panel A, Central Bank Liquidity is split by loan maturity intervals. Loans are classified as short term when maturity $\leq 1$ year, medium term when maturity is $>1$ year and $\leq 5$ years, and long term when maturity $>5$ years. In Panel B, firm size classes are determined based on the 33rd and 67th percentile of total assets of all firms in the data sample. All variables are defined in Appendix A1. The regressions include all control variables and fixed effects used in Panel B of Table 5. Standard errors are clustered at the firm and at the week level using the method as proposed by Cameron, Gelbach and Miller (2011) and Thompson (2011). The statistical significance of results is indicated by $*=10 \%$ level, $* *=5 \%$ level and $* * *=1 \%$ level.

\section{Panel A. Loan maturity}

\begin{tabular}{|c|c|c|c|c|}
\hline & $\begin{array}{c}\text { Full Sample } \\
\text { (1) }\end{array}$ & Full Sample & Intensive Margin & $\begin{array}{c}\text { Borrower } \\
\text { Characteristics } \times \\
\text { Central Bank } \\
\text { Liquidity } \\
\text { (4) }\end{array}$ \\
\hline Central Bank Liquidity $\times$ Short-term Loan & $-213.957 * *$ & & & \\
\hline Central Bank Liquidity $\times$ Medium-term Loan & -47.766 & & & \\
\hline Central Bank Liquidity $\times$ Long-term Loan & 278.729 & & & \\
\hline \multicolumn{5}{|l|}{ Central Bank Liquidity $\times$ High Bank Risk $\times$} \\
\hline (1) Short-term Loan & & $-258.339 * *$ & $-544.476 * * *$ & $-149.948 * *$ \\
\hline (2) Medium-term Loan & & 8.365 & -52.857 & 143.922 \\
\hline (3) Long-term Loan & & 322.886 & -34.632 & 340.223 \\
\hline \multicolumn{5}{|l|}{ Central Bank Liquidity $\times$ Low Bank Risk $\times$} \\
\hline (4) Short-term Loan & & $-185.332 *$ & $-564.236 * * *$ & $-122.693 *$ \\
\hline (5) Medium-term Loan & & $-201.288 * * *$ & $-318.551 * * *$ & $-100.376^{* *}$ \\
\hline (6) Long-term Loan & & 163.363 & 446.38 & 252.054 \\
\hline Central Bank Liquidity $\times$ Borrower Leverage & No & No & No & Yes \\
\hline Central Bank Liquidity $\times$ Borrower Current Ratio & No & No & No & Yes \\
\hline Bank Risk $\times$ Loan Maturity Intervals & Yes & Yes & Yes & Yes \\
\hline Bank Risk $\times$ Time FE (year) & Yes & Yes & Yes & Yes \\
\hline Further Control Variables and Fixed Effects & Yes & Yes & Yes & Yes \\
\hline Wald Test of Interaction Terms & & $0.542 / 0.0184 /$ & $0.8531 / 0.0087 /$ & $0.684 / 0.0237 /$ \\
\hline$[(1)=(4) /(2)=(5) /(3)=(6)]$ & & 0.5589 & 0.3566 & 0.8392 \\
\hline Observations & 623 & 623 & 272 & 623 \\
\hline R-squared & 0.756 & 0.758 & 0.844 & 0.764 \\
\hline
\end{tabular}

Panel B: Bank-dependence

\begin{tabular}{|c|c|c|c|c|}
\hline & $(1)$ & $(2)$ & (3) & (4) \\
\hline Central Bank Liquidity $\times$ Small Firm & -38.776 & & & \\
\hline Central Bank Liquidity $\times$ Medium Firm & $-72.799 * *$ & & & \\
\hline Central Bank Liquidity $\times$ Large Firm & $-105.442 * *$ & & & \\
\hline Central Bank Liquidity $\times$ No Rating & & & -32.224 & \\
\hline Central Bank Liquidity $\times$ Rating & & & $-283.249 * *$ & \\
\hline \multicolumn{5}{|l|}{ Central Bank Liquidity $\times$ High Bank Risk $\times$} \\
\hline (1) Small Firm & & 23.47 & & \\
\hline (2) Medium Firm & & -28.435 & & \\
\hline (3) Large Firm & & $-92.366 * *$ & & \\
\hline (4) No Rating & & & & 2.242 \\
\hline (5) Rating & & & & $-74.360 *$ \\
\hline \multicolumn{5}{|l|}{ Central Bank Liquidity $\times$ Low Bank Risk $\times$} \\
\hline (6) Small Firm & & $-184.946 * *$ & & \\
\hline (7) Medium Firm & & $-196.643 * * *$ & & \\
\hline (8) Large Firm & & $-155.411 * *$ & & \\
\hline (9) No Rating & & & & $-138.785 * * *$ \\
\hline (10) Rating & & & & $-295.622 * * *$ \\
\hline Bank Risk $\times$ Firm Size Intervals & Yes & Yes & No & No \\
\hline Bank Risk × Rating Dummy & No & No & Yes & Yes \\
\hline Bank Risk $\times$ Time FE (year) & Yes & Yes & Yes & Yes \\
\hline Further Control Variables and Fixed Effects & Yes & Yes & Yes & Yes \\
\hline $\begin{array}{l}\text { Wald Test of Interaction Terms } \\
{[(1)=(6) /(2)=(7) /(3)=(8)]}\end{array}$ & & $0.0139 / 0.0017 / 0.0513$ & & \\
\hline $\begin{array}{l}\text { Wald Test of Interaction Terms } \\
{[(4)=(9) /(5)=(10)]}\end{array}$ & & & & $0.0063 / 0.0422$ \\
\hline Observations & 623 & 623 & 623 & 623 \\
\hline R-squared & 0.729 & 0.734 & 0.732 & 0.751 \\
\hline
\end{tabular}




\section{Table 9. Debt capital structure and firm characteristics}

This table reports propensity score matching (PSM) results of changes in borrower characteristics of borrowers along the intensive margin in the full allotment period. All variables are derived at the firm level and measured in real terms with 2006 as the base year using the Consumer Price Index (CPI) as published by the OECD. Asset Growth is the ratio of total assets in $t$ divided by the value of total assets in $t-1$, minus 1 . Payouts are total dividends, Capex are capital expenditures, Investment is total invested capital, and Employment is the number of employees in thousand. The panels show regression results of either percentage point differences (Term Loans/Total Debt, Revolving Loans/Total Debt, Notional Outstanding/Total Debt, and Asset Growth), or log differences (Total Liabilities, Payouts, Capex, and Investments) or differences (Employment) from year $t$ to $t+1, t$ to $t+2$, and $t$ to $t+3$, with $t$ as the year when the loan is initiated in the full allotment period. Regression results of these variables including control variables and fixed effects used in Panel B of Table 5 are shown in Online Appendix I. All variables are defined in Appendix A1. We use a Gaussian kernel estimator with a bandwidth of 0.01 . The statistical significance of results is indicated by $*=10 \%$ level, $* *=5 \%$ level and $* * *=1 \%$ level using 50 bootstrap replications.

\begin{tabular}{lccc}
\hline & $\Delta(t ; t+1)$ & $\Delta(t ; t+2)$ & $\Delta(t ; t+3)$ \\
& $(1)$ & $(2)$ & $(3)$ \\
Method & PSM & PSM & PSM \\
\hline Capital Structure & & & \\
Term Loans/Total Debt & $-1.959^{* *}$ & $-6.799^{* * *}$ & $-6.293^{* *}$ \\
Revolving Loans/Total Debt & $5.353^{* *}$ & $5.098^{* *}$ & $5.462^{* * *}$ \\
Notional Outstanding/Total Debt & 0.576 & -0.612 & -1.067 \\
Total Liabilities & -0.015 & -0.111 & -0.073 \\
Investments \& Employment & & & \\
Payouts & 0.017 & $-0.124^{*}$ & 0.019 \\
Capex & 0.017 & $-0.170^{*}$ & $-0.158^{*}$ \\
Asset Growth & 5.35 & 1.163 & 3.02 \\
Investments & -0.018 & $-0.143^{*}$ & $-0.052^{*}$ \\
Employment & -0.95 & $-12.414^{* *}$ & $-31.133^{* *}$ \\
\hline
\end{tabular}




\section{Appendix A1. Description of key variables}

The table provides descriptions of all variables. All financial variables are winsorized at the 1st and 99th percentile and measured in real terms with 2006 as the base year using the Consumer Price Index (CPI) as published by the OECD.

\begin{tabular}{|c|c|}
\hline Variable & Definition \\
\hline Central Bank Liquidity & $\begin{array}{l}\text { Natural logarithm of the absolute amount of liquidity in the banking sector. It } \\
\text { is calculated as the logarithm of the sum of banks' current account and deposit } \\
\text { facility holdings with the ECB. by the ECB ex post on a daily basis in the } \\
\text { "Data on daily liquidity conditions." The variable is centered around its mean } \\
\text { value in } 2006 \text {. }\end{array}$ \\
\hline \multicolumn{2}{|l|}{ Instruments } \\
\hline $\begin{array}{l}\text { End of Reserve Maintenance } \\
\text { Period }\end{array}$ & $\begin{array}{l}\text { Dummy variable, which is } 1 \text { on the last day of the ECB's reserve maintenance } \\
\text { period. }\end{array}$ \\
\hline Excess Cash & $\begin{array}{l}\text { Excess Cash is a continuous measure of firms' aggregate quarterly excess cash } \\
\text { holdings. }\end{array}$ \\
\hline \multicolumn{2}{|r|}{ 10 } \\
\hline ECB Deposit Facility Rate & $\begin{array}{l}\text { Interest rate at which banks can deposit funds overnight at the ECB deposit } \\
\text { facility. }\end{array}$ \\
\hline Deposit Spread (bps) & Spread between the deposit interest rate and the ECB deposit facility rate. \\
\hline Log(Notional Deposit Amount) & Natural logarithm of the notional $€$ deposit amount. \\
\hline Duration (days) & The duration of the deposit transaction. \\
\hline Bank Competition & $\begin{array}{l}\text { Sum of the squared market share of each bank over the last week using } \\
\text { deposit volume. }\end{array}$ \\
\hline \multicolumn{2}{|r|}{ 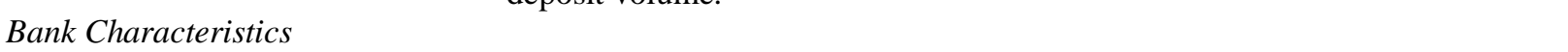 } \\
\hline Bank Risk & $\begin{array}{l}\text { Credit default swap spread in bps on the bank's senior unsecured debt with a } \\
\text { five-year maturity. }\end{array}$ \\
\hline High (Low) Bank Risk & Indicator whether bank is high (low) bank risk based on its CDS spread. \\
\hline Capital Adequacy & Leverage ratio (total liabilities/total assets) lagged by one year. \\
\hline Liquidity & $\begin{array}{l}\text { Liquid assets/short-term funding; total deposits/total assets; net } \\
\text { loans/customer deposits; off-balance sheet exposure; lagged by one year. }\end{array}$ \\
\hline Profitability & Net interest margin; cost/income-ratio; return on assets; lagged by one year. \\
\hline Asset Quality & Non-performing loans/total loans. \\
\hline Investments & $\begin{array}{l}\text { Total assets; total asset growth; net derivatives exposure/total assets; lagged } \\
\text { by one year. }\end{array}$ \\
\hline \multicolumn{2}{|l|}{ Borrower Variables } \\
\hline Borrower Characteristics & $\begin{array}{l}\text { Total assets; leverage (total liabilities/total assets); current ratio; interest } \\
\text { coverage ratio; market-to-book ratio; tangible assets/total assets; rating/no } \\
\text { rating dummy or rating classes (based on S\&P ratings); lagged by one year. }\end{array}$ \\
\hline \multicolumn{2}{|r|}{ 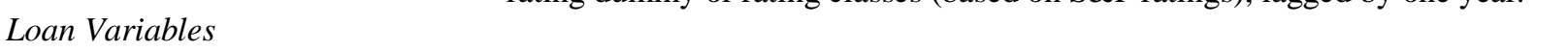 } \\
\hline AISD (bps) & $\begin{array}{l}\text { Coupon spread over LIBOR plus one time fees on the drawn portion of the } \\
\text { loan as stated in DealScan. }\end{array}$ \\
\hline Loan Characteristics & $\begin{array}{l}\text { Facility size; maturity; secured dummy; performance pricing dummy; } \\
\text { currency. }\end{array}$ \\
\hline Loan Type & Term loan; credit line ( $>$ or <= 1 year); bridge loan. \\
\hline Loan Purpose & Corporate purposes; M\&A; debt repayment; working capital; other purpose. \\
\hline \multicolumn{2}{|l|}{ Macro Environment } \\
\hline $\begin{array}{l}\text { Three-Month EURIBOR-EONIA } \\
\text { Swap Spread }\end{array}$ & $\begin{array}{l}\text { Spread between the three-month EURIBOR and the three-month EONIA } \\
\text { swap. }\end{array}$ \\
\hline Quarterly EU GDP Growth (\%) & The quarterly growth rate of the gross domestic product at market prices. \\
\hline CISS & Composite Indicator of Systemic Stress as published by the ECB. \\
\hline
\end{tabular}

Online Appendix A contains a more detailed description of all variables including detailed descriptive statistics. 


\section{Appendix A2. Sample}

This table shows the construction of the loan-level dataset. Panel A shows how we arrive from the universe of loans to our sample. Panel B reports the results of a comparison of the regression sample with a larger sample, which includes the loans not originated by our sample banks.

Panel A: Loan sample selection

All Loan Facilities in DealScan: 2006-2010:Q2

63,991

Match Chava-Roberts (2008) Linking File

$-42,982=\quad 21,009$

Merge Compustat Data

$-8,614=\quad 12,395$

Clean DealScan Data (e.g., Spread Included, Notional Reported)

$-2,527=\quad 9,868$

Restrict Sample to European Banks Which Also Operate on Platform

$-7,236=\quad 2,632$

Panel B: Differences in loan and borrower characteristics due to restriction of sample to platform banks

\begin{tabular}{lc}
\hline & $\Delta$ (Included - Excluded) \\
\hline Loan Characteristics & \\
All in Spread Drawn (bps) & 2.327 \\
Facility Size (€ million) & $417 * * *$ \\
Maturity in Months & 0.248 \\
Borrower Characteristics & \\
Total Assets ( $€$ million) & $4,459 * * *$ \\
Leverage & $0.017 * *$ \\
Current ratio & $-0.069^{*}$ \\
Coverage & $-14.021^{* * *}$ \\
Market-to-Book & -0.032 \\
Tangibility & $0.049 * * *$ \\
\hline
\end{tabular}




\section{Appendix A3. Exemplary deposit auction}

This table shows an exemplary deposit transaction for illustrative purposes.

\begin{tabular}{|c|c|c|c|c|c|c|c|c|c|c|c|}
\hline Time of Trade & Firm ID & $\begin{array}{l}\text { Bank } \\
\text { Name }\end{array}$ & $\begin{array}{l}\text { Maturity } \\
\text { Date }\end{array}$ & $\begin{array}{l}\text { Transaction } \\
\text { Start Date }\end{array}$ & Time of Bank Bid & Product & Currency & Status & $\begin{array}{l}\text { Status of } \\
\text { Bank Bid }\end{array}$ & $\begin{array}{l}\text { Notional } \\
\text { Amount }\end{array}$ & $\begin{array}{l}\text { Quote } \\
\text { Value }\end{array}$ \\
\hline 14-11-2005 12:35:58 & $\mathrm{XXXXXXXX}$ & Bank1 & $15-11-2005$ & $14-11-2005$ & $14-11-2005$ 12:35:43 & Deposit & EUR & EXEC & LCAN & $76,200,000$ & 2.06 \\
\hline $14-11-2005$ 12:35:58 & $\operatorname{xxxxxxxx}$ & Bank2 & $15-11-2005$ & $14-11-2005$ & $14-11-2005$ 12:35:34 & Deposit & EUR & EXEC & EXEC & $76,200,000$ & 2.08 \\
\hline 14-11-2005 12:35:58 & $\operatorname{xxxxxxxx}$ & Bank3 & $15-11-2005$ & $14-11-2005$ & $14-11-2005$ 12:35:33 & Deposit & EUR & EXEC & LCAN & $76,200,000$ & 2.07 \\
\hline 14-11-2005 12:35:58 & $\operatorname{xxxxxxxx}$ & Bank4 & $15-11-2005$ & $14-11-2005$ & 14-11-2005 12:35:35 & Deposit & EUR & EXEC & LCAN & $76,200,000$ & 2.05 \\
\hline $14-11-2005$ 12:35:58 & $\operatorname{xxxxxxxx}$ & Bank5 & $15-11-2005$ & $14-11-2005$ & $14-11-2005$ 12:35:39 & Deposit & EUR & EXEC & LCAN & $76,200,000$ & 2.06 \\
\hline 14-11-2005 12:35:58 & $\operatorname{xxxxxxxx}$ & Bank6 & $15-11-2005$ & $14-11-2005$ & 14-11-2005 12:35:26 & Deposit & EUR & EXEC & LCAN & $76,200,000$ & 2.07 \\
\hline
\end{tabular}

\begin{tabular}{ll}
\hline Trade Number & Identifying number for a specific trade. \\
Time of Trade & Time when the auction is closed. It shows the date and the exact time in seconds. All transactions are executed on the same day. \\
Firm ID & Numerical identifier for each firm, anonymized for confidentiality reasons. \\
Bank Name & Bank names available but changed for confidentiality reasons. \\
Maturity Date & The maturity of the trade. \\
Transaction Start Date & The start date of the trade. \\
Time of Bank Bid & The exact time a bank is bidding for a deposit amount. If a bank provides several bids in a transaction we use the last bid of this bank. \\
Product & The product which is traded. \\
Currency & The currency of the product. \\
Status & The status of the entire auction. EXEC means that the trade is executed. \\
Status of Bank Bid & The status of each bank's bid in the auction. LCAN means ListCancel, that is, another bank bid was selected by the firm. EXEC depicts the \\
& executed trade. \\
Notional Amount & The notional amount banks bid for. \\
Quote Value & The deposit interest rate banks are bidding in the auction. Banks bid an annual interest rate in percent using an actual/360 day count \\
& convention.
\end{tabular}




\section{Appendix A4. Excess cash}

This appendix describes the methodology for computing excess cash holdings for European non-financial firms using Compustat Global data. Based on previous approaches described in Fresard and Salva (2010), we estimate the following model quarterly for firm $i$ 's cash holdings:

$$
\begin{gathered}
\ln \left(\text { Cash }_{i}\right)=\beta_{1} \ln \left(T A_{i}\right)+\beta_{2} \ln \left(C F_{i}\right)+\beta_{3} \ln \left(N W C_{i}\right)+\beta_{4} \ln \left(M V_{i}\right) \\
+\beta_{5} \ln \left(\text { Capex }_{i}\right)+\beta_{6} \ln \left(\text { Leverage }_{i}\right)+\Phi+\varepsilon_{i}
\end{gathered}
$$

Where Cash is cash and marketable securities over total assets, $T A$ is total assets in euros, $C F$ is EBITDA over total assets, $N W C$ is current assets minus current liabilities minus cash over total assets. $M V$ is the market value of the firm, computed as the sum of the market value of equity and the book value of short-term and long-term debt divided by total assets. Capex is capital expenditures over total assets, Leverage is the sum of short-term and long-term debt over total assets. $\Phi$ is an industry-fixed effect. ${ }^{1}$

We then define excess cash as the difference between actual cash and the predicted normal cash obtained from the estimation. We aggregate excess cash holdings to a quarterly measure using a firm's total assets as weights.

Based on quarterly cash holdings, we construct two possible instruments: (1) a continuous variables excess cash that varies quarterly, and (2) an indicator variable that is 1 if excess cash exceeds its long-run mean in a quarter (measured over a 15 -year period prior to the beginning of our sample period).

\footnotetext{
${ }^{1}$ Note that estimating the model with or without fixed effects does not qualitatively change the results in the main regressions.
} 